\title{
The Inflammasome in Times of COVID-19
}

\section{Juan Carlos de Rivero Vaccari ${ }^{1}$, W. Dalton Dietrich ${ }^{2}$, Robert W. Keane ${ }^{2,3}$ and Juan Pablo de Rivero Vaccari ${ }^{2,4 *}$}

${ }^{1}$ DRV Ventures, LLC, Miami, FL, United States, ${ }^{2}$ Department of Neurological Surgery and The Miami Project to Cure Paralysis, University of Miami Miller School of Medicine, Miami, FL, United States, ${ }^{3}$ Department of Physiology and Biophysics, University of Miami Miller School of Medicine, Miami, FL, United States, ${ }^{4}$ Center for Cognitive Neuroscience and Aging University of Miami Miller School of Medicine, Miami, FL, United States

Coronaviruses (CoVs) are members of the genus Betacoronavirus and the Coronaviridiae family responsible for infections such as severe acute respiratory syndrome (SARS), Middle East respiratory syndrome (MERS), and more recently, coronavirus disease-2019 (COVID-19). CoV infections present mainly as respiratory infections that lead to acute respiratory distress syndrome (ARDS). However, CoVs, such as COVID-19, also present as a hyperactivation of the inflammatory response that results in increased production of inflammatory cytokines such as interleukin (IL)-1 $\beta$ and its downstream molecule IL-6. The inflammasome is a multiprotein complex involved in the activation of caspase- 1 that leads to the activation of IL-1 $\beta$ in a variety of diseases and infections such as CoV infection and in different tissues such as lungs, brain, intestines and kidneys, all of which have been shown to be affected in COVID-19 patients. Here we review the literature regarding the mechanism of inflammasome activation by $\mathrm{CoV}$ infection, the role of the inflammasome in ARDS, ventilator-induced lung injury (VILI), and Disseminated Intravascular Coagulation (DIC) as well as the potential mechanism by which the inflammasome may contribute to the damaging effects of inflammation in the cardiac, renal, digestive, and nervous systems in COVID-19 patients.

\section{Keywords: inflammasome, COVID-19, inflammation, coronavirus, caspase-1, IL-1beta}

Coronaviruses (CoVs) are members of the genus Betacoronavirus and the Coronaviridiae family. $\mathrm{CoVs}$ are enveloped positive-sense single stranded RNA viruses ( $\sim 30 \mathrm{~Kb}$ in length) that encode for viral replicase. In addition, the outer envelope of CoVs is comprised of the spike (S), envelope (E), and membrane $(\mathrm{M})$ glycoproteins; whereas the nucleocapsid $(\mathrm{N})$ comprises the inner core (1). $\mathrm{CoVs}$ bind to angiotensin converting enzyme-2 (ACE2) receptors in host cells through the S protein (Figure 1) (2). The $\mathrm{M}$ and $\mathrm{E}$ glycoproteins are involved in viral assembly $(3,4)$ and the $\mathrm{N}$ protein coats the viral genome (5). In addition, CoVs also have the accessory proteins $3 \mathrm{a}, 3 \mathrm{~b}, 6,7 \mathrm{~b}, 8 \mathrm{a}, 8 \mathrm{~b}$, and $9 \mathrm{~b}$.

In 2002, CoVs were responsible for severe acute respiratory syndrome (SARS) $(6,7)$; in 2012, CoVs were responsible for Middle East respiratory syndrome (MERS), and currently since 2019, the SARS coronavirus-2 (SARS-CoV-2) is responsible for coronavirus disease-2019 (COVID-19) (8).

It is evident that the rate at which new $\mathrm{CoV}$ infections are affecting humans is increasing. Thus, a better understanding of the mechanism of $\mathrm{CoV}$ infection is needed as well as the manifestations of 


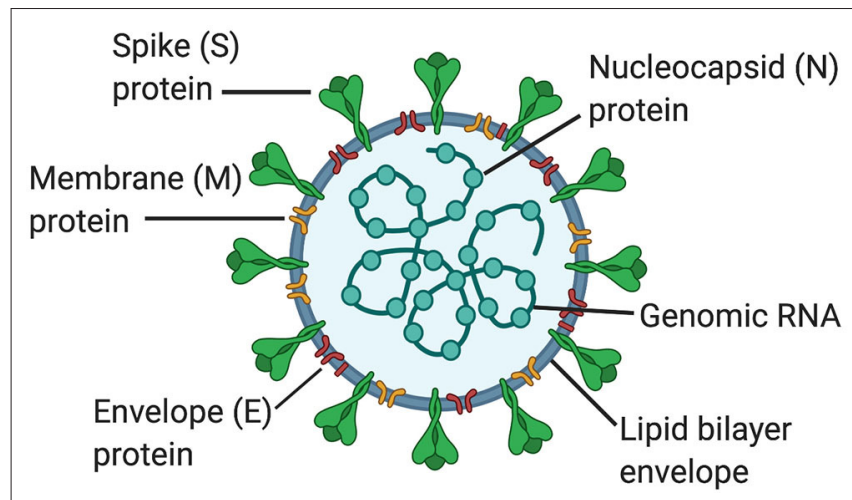

FIGURE 1 | Structure of coronaviruses. In a lipid bilayer envelope, CoVs consist of a spike (S) protein, a membrane (M) protein and an envelope (E) protein. Inside the lipid bilayer envelope, the nucleocapsid $(\mathrm{N})$ protein and the genomic RNA comprise the inner core.

symptoms and systemic complications associated with these infections in order to develop better therapies against COVID-19. Here we review the literature on the role of the inflammasome in $\mathrm{CoV}$ infections, which includes how CoVs activate inflammasomes upon infection, the role of the inflammasome in acute respiratory distress syndrome (ARDS), how ventilator-induced lung injury (VILI) activates the inflammasome, how the inflammasome plays a role in the systemic complications associated with COVID-19, and how the inflammasome is involved in the process of Disseminated Intravascular Coagulation (DIC).

\section{THE INFLAMMASOME}

The inflammasome is a multiprotein complex of the innate immune response initially described as a regulator of caspase1 activation and processing of the pro-inflammatory cytokines interleukin (IL)-1 $\beta$ and IL-18 (9). These multiprotein complexes are comprised of three basic components: (1) A sensor such as a NOD-like receptor (NLR) or an AIM-2 like receptor (ALR) (2) the adaptor protein apoptosis-associated speck-like protein containing a caspase-recruitment domain (ASC) and (3) the inflammatory cysteine aspartase caspase-1. Inflammasomes are named after their sensor proteins which include NLRP1, NLRP2, NLRP3, NLRC4, and AIM2, with NLRP3 being the most extensively studied inflammasome to date (10).

In addition to its role in cytokine production, the inflammasome is also involved in the cleavage of gasdermin-D (GSDM-D) in the cell death process of pyroptosis (11). GSDM-D is cleaved at the linker region between the amino $(\mathrm{N})$ and carboxy (C) terminus by either caspase- 1 and/or caspase- 4 or -5 in humans (caspase-11 in rodents), resulting in freeing of the $\mathrm{N}$-terminus from autoinhibiting the C-terminus, which allows formation of a pore by the N-terminus (GSDM-D-N) in the cell membrane (Figure 2) (12).

Inflammasomes were initially described for their role in mounting an innate immune response against bacterial (9), viral (13), and fungal (14) infections as well as in autoimmune diseases (15). However, lately, most attention has been paid to the role of inflammasomes in diseases such as rheumatoid arthritis (16), gout (17), diabetes (18), heart disease (19), renal diseases (20), hepatic diseases (21), psoriasis (22), vitiligo (23), multiple sclerosis (24, 25), Alzheimer's disease (26), Parkinson's disease (27), as well as central nervous system (CNS) injury (28-30), among others.

Each inflammasome is activated by different ligands which can either be endogenous or exogenous. Endogenous ligands are referred to as damage/danger-associated molecular patterns (DAMPs), and exogenous ligands are referred to as pathogenassociated molecular patterns (PAMPs). Examples of DAMPs include adenosine tri-phosphate or mitochondrial DNA (31). However, in the context of COVID-19, SARS-CoV-2 represents a PAMP capable of activating the inflammasome. During viral infections, inflammasomes play a role in the response to influenza virus (32), encephalomyocarditis virus (33), vesicular stomatitis virus (33), hepatitis C virus (34), respiratory syncytial virus (35), vesicular stomatitis virus (33), west Nile virus (36), Zika virus (37), swine fever virus (38), Ebola virus (39), H1N1 virus (40), Sendai virus (41), herpes simplex virus (42), Leishmania RNA virus (43), Dengue virus (44), human immunodeficiency virus (45), and CoVs (46).

The process of inflammasome activation involves a twostep process (Figure 2). The first step is referred to as signal 1 and represents the priming step of inflammasome activation in which a PAMP or DAMP binds to a pattern recognition receptor (PRR) such as toll-like receptor (TLR)-4 to stimulate the synthesis of pro-IL-1 $\beta$ and pro-IL-18 in a nuclear factor (NF)-кB-dependent manner (47). Once these pro-inflammatory cytokines are formed, then a second signal is needed to induce inflammasome formation and subsequent processing of proIL-1 $\beta$ and pro-IL-18 into its active forms which are then secreted by different mechanisms. One of these mechanisms includes the GSDM-D pore, which is formed by the N-terminus of GSDM-D that is inserted in the membrane (GSDMD-N) following GSDM-D cleavage (48). Inflammasome formation involves a process in which the sensor molecule such as NLRP3 oligomerizes and then the adaptor protein ASC is recruited into the complex, followed by incorporation of caspase-1, which is then autoproteolytically cleaved into its active form. This cleaved or active form of caspase- 1 then exerts its catalytic activity on the pro-inflammatory cytokines that after their release perpetuate the inflammatory response (31). Although there is no unifying consensus regarding the mechanism of inflammasome activation, various processes have been proposed to contribute to the second signal of inflammasome activation such as high extracellular $\mathrm{K}^{+}$ concentration, $\mathrm{K}^{+}$efflux, mitochondrial dysfunction, formation of reactive oxygen species (ROS), oxidized mitochondrial DNA, lysosomal degradation, and $\mathrm{Ca}^{2+}$ imbalance (Figure 2) $(49,50)$.

\section{THE INFLAMMASOME AND CORONAVIRUSES}

Viroporins are hydrophobic proteins that facilitate release of viral proteins from infected cells by modifying the cell membrane, 


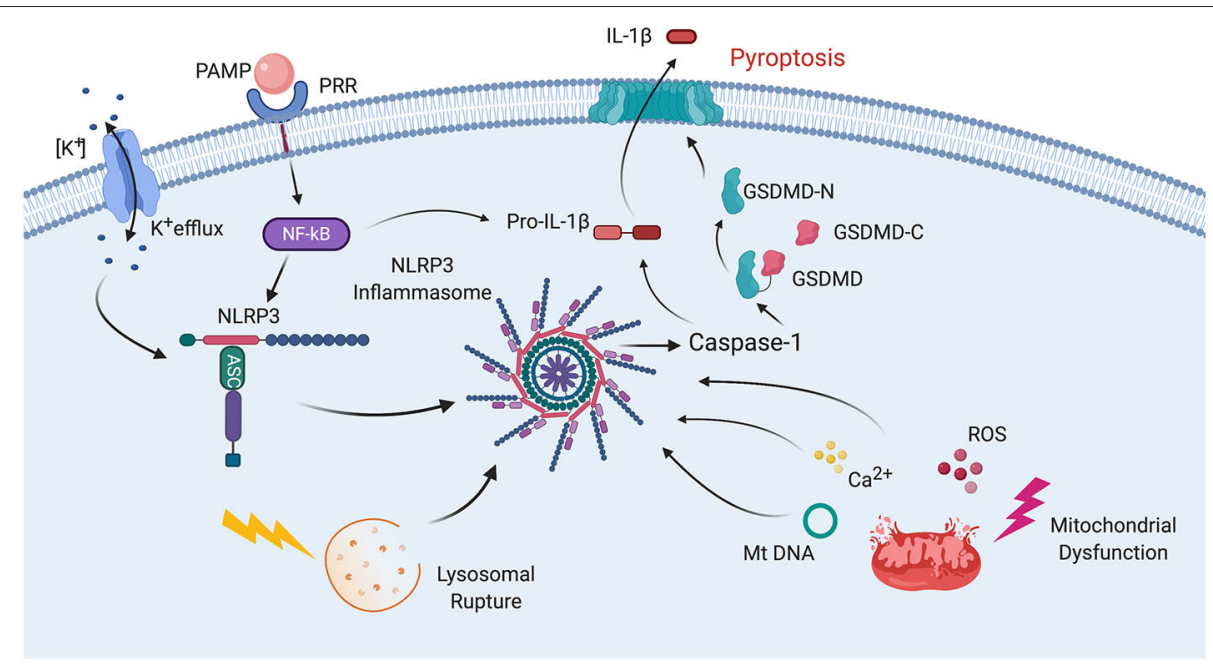

FIGURE 2 | Mechanisms of inflammasome activation. Inflammasome activation in general relies on two signals for its activation. First, a PAMP binds to a PRR resulting in synthesis of NLRP3 and pro-IL-1 $\beta$. Then a second signal leads to inflammasome assembly, leading to the activation of caspase- 1 , processing of pro-IL-1 $\beta$ into IL-1 $\beta$ and pyroptosis. The second signal may come from a variety of pathways including $\mathrm{K}^{+}$efflux. Lysosomal rupture or mitochondrial dysfunction. Mitochondrial dysfunction results in release of ROS, $\mathrm{Ca}^{2+}$ and mitochondrial DNA (mtDNA), all of which have been shown to activate the inflammasome. Pyroptosis occurs as a result of caspase-1-mediated cleavage of GSDM-D at the linker region of GSDM-D. Following GSDM-D cleavage, the amino terminus of GSDM-D (GSDM-D-N) forms a non-selective pore at the cell membrane through which IL-1 $\beta$ is then released.

and they are involved in the activation of inflammasomes. Viroporins are associated in viral pathogenesis, and their low ionic selectivity makes them ideal candidates for ionic exchange, which is critical for viral infection and inflammasome activation (Figure 3). When viroporins are blocked or deleted, the severity of infections tends to decrease (51), making viroporins attractive for the development of therapies to prevent exacerbation of the inflammatory response associated with viral infections (Table 1).

The E glycoprotein of $\mathrm{CoV}$ forms a membrane pore that allows the passage of ions (56). Mice infected with $\mathrm{E}$ protein viruses developed pulmonary edema (46), which is characteristic of ARDS, and a main cause of death associated with $\mathrm{CoV}$ infections $(57,58)$. In addition to edema following pore activity mediated by the E protein, high levels of the inflammasome-mediated proinflammatory cytokine IL-1 $\beta$ have been detected in the lung parenchyma (52). This finding suggests the involvement of the inflammasome in the mechanism of $\mathrm{CoV}$ infection.

Lack of ion exchange through the E protein following SARS$\mathrm{CoV}$ infection results in lower levels of IL- $1 \beta$ and lower immunerelated pathology. The events associated with over-activation of the immune response tend to be more damaging to the host than the response associated with cell death in the host induced by the virus (59). Thus, a modulation of the immune inflammatory response is as critical, if not more, than preventing cell death induced by viruses. This observation makes the inflammasome, the master regulator of IL-1 $\beta$, a key target for $\mathrm{CoV}$ infections. In addition to the role of viroporin $\mathrm{E}$ in $\mathrm{Ca}^{2+}$. mediated inflammasome activation, the accessory protein $3 \mathrm{a}$, which potentially acts as a $\mathrm{K}^{+}$channel, has also been shown to activate the NLRP3 inflammasome (Figure 3) (53).

Like viroporin E, SARS-CoV open reading frame3a (ORF3a) acts as an ion channel $\left(\mathrm{Na}^{+}, \mathrm{K}^{+}, \mathrm{Ca}^{2+}\right)(60)$. However, in regards to inflammasome activation, it seems that ORF3a promotes NLRP3 inflammasome activation by modulating the ubiquitination of the inflammasome adaptor protein ASC and the production of pro-IL- $1 \beta$ by activation of $N F-\kappa B$, which is independent of the ion-channel role that ORF3a plays. Furthermore, release of active IL- $1 \beta$ following activation of the NLRP3 inflammasome is dependent on tumor necrosis factor (TNF) receptor-associated factor 3 (TRAF3) (54). However, a similar effect was not detected for the AIM2 inflammasome. The effects of ORF3a on the priming (signal 1) and the processing (signal 2) of pro-IL-1 $\beta$ on inflammasome activation suggests a mechanism by which one protein is responsible for both signaling events needed for inflammasome activation, unlike other infectious mechanisms that rely on lipopolysaccharide (LPS) for the priming step (step 1) and adenosine tri-phosphate (ATP) for the activation step (step 2) (Figure 3). Interestingly, ORF3a is also able to process pro-IL-1 $\beta$ in an ASC-dependent but NLRP3-independent manner (54).

Shi et al. showed that ORF8b triggers NLRP3 inflammasome activation and IL-1 $\beta$ release by binding to the leucine rich repeat (LRR) domain of NLRP3, resulting in macrophage pyroptosis (55). In this study, the authors demonstrated that ORF8b formed insoluble protein aggregates. Moreover, ORF8b aggregates seemed to interact with NLRP3 and ASC forming a single speck (Figure 3). Considering that ASC specks have prionoid properties that interact with other pathogenic protein aggregates such a amyloid- $\beta$, resulting in a more exacerbated inflammatory response, a deeper understanding regarding the role of ORF8b aggregates following $\mathrm{CoV}$ infections would be beneficial to understanding the innate immune response mounted by these infections (61). 


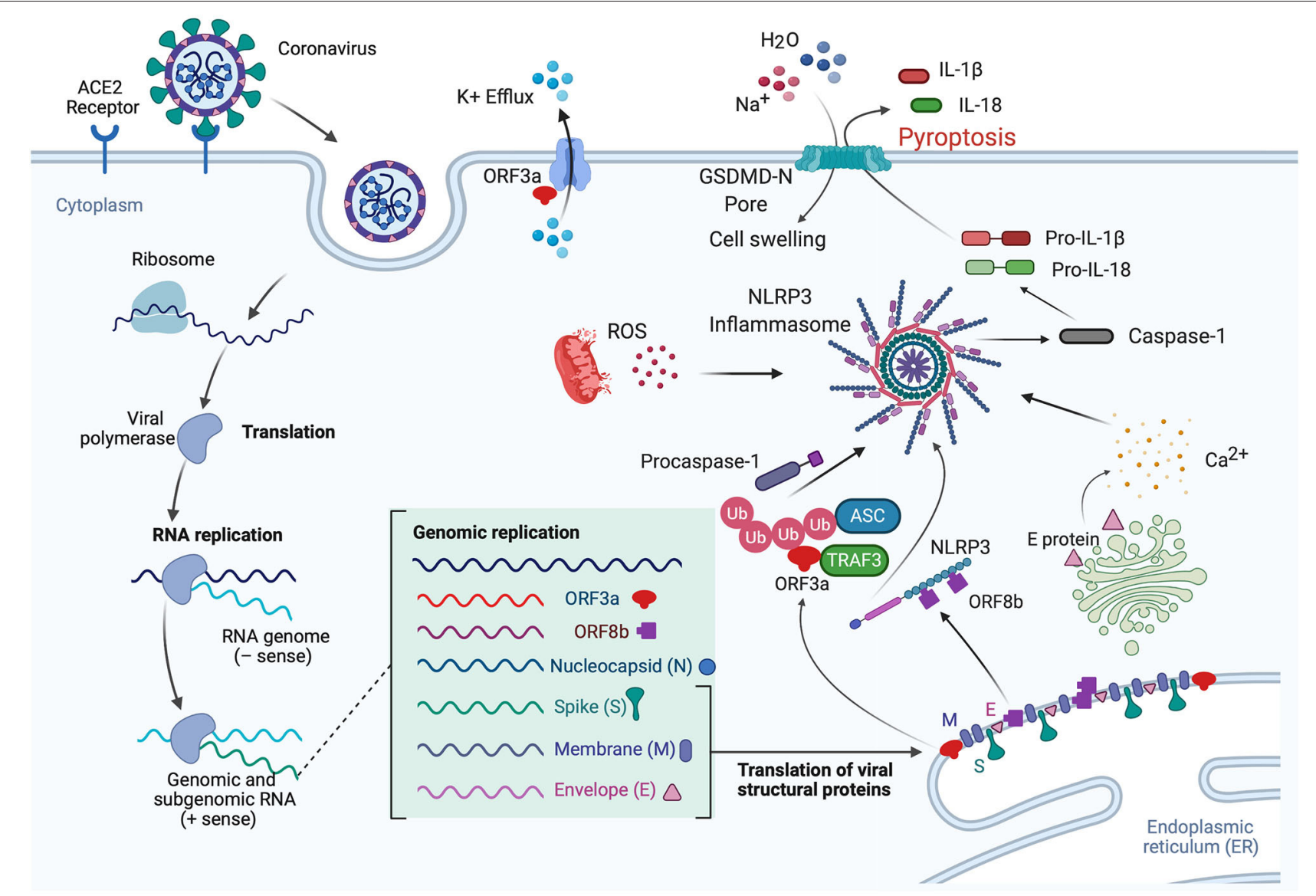

FIGURE 3 | Mechanisms of inflammasome activation in CoV infection. In the lungs when the S protein of SARS-CoV-2 binds to the ACE2 receptor, the virus is internalized by endocytosis, leading to translation and RNA replication of genomic and sub-genomic RNA including ORF3a, ORF8b, and the viral structural proteins ( $N, \mathrm{~S}, \mathrm{M}$, and $\mathrm{E}$ proteins). The E protein is involved in $\mathrm{Ca}^{2+}$ release from the Golgi apparatus. This $\mathrm{Ca}^{2+}$ has the potential to activate the inflammasome. In addition, ORF3a interacts with TRAF3 to ubiquitinate ASC, and ORF8b interacts with NLRP3, resulting in inflammasome activation and pyroptosis. IL-1 $\beta$ is released through the GSDM-D-N pore during pyroptosis, while $\mathrm{Na}^{+}$and $\mathrm{H}_{2} \mathrm{O}$ molecules enter the cell, resulting in cell swelling, which then manifests as pulmonary edema. Furthermore, ORF3a also acts in the cell membrane as a $\mathrm{K}^{+}$channel, which causes an ionic imbalance also capable of promoting inflammasome activation, and mitochondrial dysfunction produces ROS that also contribute to inflammasome activation.

Consistent with previous studies regarding the mechanisms of inflammasome activation, it has been shown that $\mathrm{Ca}^{2+}$ imbalance is a common denominator in a variety of viral infections that result in inflammasome activation such as influenza (62), and encephalomyocarditis virus (63). Ionic imbalance has been associated with inflammasome activation in the lung following infections (64), and consistent with this finding is a recent study by Nieto-Torres et al. showing that E protein from SARS$\mathrm{CoV}$ makes a $\mathrm{Ca}^{2+}$ permeable channel in the endoplasmic reticulum (ER)/Golgi intermediate compartment (ERGIC)/Golgi membrane that results in NLRP3 inflammasome activation and increased levels of IL-1 $\beta$ (Figure 3) (46).

The macrodomain of SARS Unique Domain (SUD) known as SUD-MC is involved in the activation of the chemokine CXCL10 and IL-1 $\beta$ in lung epithelial cells as determined by the levels of IL-1 $\beta$ in bronchioalveolar lavage fluid (BALF) (65). This process is mediated by the NLRP3 inflammasome in a c-Jun-dependent pathway. However, a similar effect was not detected in NLRP3 knockout mice, indicating that NLRP3 is the main inflammasome responsible for this SUD-MC-mediated effect.

In contrast, the inflammasome also plays a protective role following murine $\mathrm{CoV}$ infection (66). The mouse hepatitis virus (MHV) strain-A59 (MHV-A59) is a positive-strand RNA virus, like SARS-CoV-2, that is used to study CoV infections with effects in the CNS, liver, spleen, and lungs. Using this model, Zalinger et al. illustrated that inflammasome activation contributes to control of viral replication through IL-18. IL-18 knockout mice presented poor survival and increased viral replication (66). Furthermore, IL-18 was involved in production of interferon (IFN) $-\gamma$ in activated T-cells. The authors showed that caspase- 1 and caspase-11 knockout mice were more susceptible to MHV infection. Nonetheless, survival increased in IL-1 knockout mice when compared to wildtype, even when the viral load was higher in the IL-1 knockouts (66). Therefore, as a result of the different effects of each inflammasome signaling protein on viral load and survival, care must be taken when considering therapies that 
TABLE 1 | CoV proteins and their role of inflammasome activation.

\begin{tabular}{|c|c|c|}
\hline $\begin{array}{l}\text { Viroporin/ } \\
\text { accessory } \\
\text { proteins }\end{array}$ & Function & References \\
\hline$E$ & $\begin{array}{l}\text { - High levels of IL-1 } 1 \beta \text { detected in the lung } \\
\text { parenchyma following CoV infection } \\
\text { - Lack of ion exchange following SARS-CoV } \\
\text { infection lowers IL-1 } \beta \\
\text { - } \mathrm{Ca}^{2+} \text {-mediated inflammasome activation }\end{array}$ & (52) \\
\hline $3 a$ & $\begin{array}{l}\text { - Acts as a } \mathrm{K}^{+} \text {channel } \\
\text { - NLRP3 inflammasome activation }\end{array}$ & (53) \\
\hline ORF3a & $\begin{array}{l}\text { - } \mathrm{Na}^{+} \text {and } \mathrm{Ca}^{2+} \text { channel } \\
\text { - Promotes NLRP3 inflammasome activation by } \\
\text { ubiquitinating ASC } \\
\text { - Production of pro-IL-1 } \beta \text { by NF-kB } \\
\text { - Processes ASC-dependent/NLRP3- } \\
\text { independent pro-IL-1 } \beta\end{array}$ & (54) \\
\hline ORF8b & $\begin{array}{l}\text { - Binds to LRR in NLRP3 to induce } \\
\text { inflammasome activation and IL-1 } \beta \text { release } \\
\text { - Causes macrophage pyroptosis } \\
\text { - Forms insoluble protein aggregates that } \\
\text { interact with ASC and NLRP3 }\end{array}$ & (55) \\
\hline
\end{tabular}

aim to block inflammasome activation for in certain infections, the lack of inflammasome activation may result in death, which is probably due to the negative consequences associated with a suppressed immune response (67). Accordingly, ASC and caspase-1 have been shown to be necessary for protective adaptive immunity against influenza. However, in that study, a similar role was not found for NLRP3 (32), yet other reports have shown an important involvement of NRLP3 following influenza infection $(67,68)$, which adds further complexity to the understanding of inflammasome signaling following viral infections.

MHV strain-3 (MHV-3) causes a viral fulminant hepatitis that results in production of fibrinogen-like protein-2 (FGL2), a monocyte/macrophage-specific procoagulant (69). This procoagulant effect may contribute to pathomechanisms that trigger DIC. Guo et al. showed that MHV-3 infection increased the levels of IL-1 $\beta$ in the serum and liver of mice. They also showed that the levels of FGL2 from macrophages was diminished in IL-1R1 knockout mice, and this finding was consistent with decreased infiltration of $\mathrm{CD} 45^{+} \mathrm{Gr}-1^{\text {high }}$ neutrophils. In addition, ROS derived from the NADPH oxidase complex (NOX) resulted in NLRP3 inflammasome activation; thus, NLRP3 and caspase-1 knockouts showed lower levels of IL-1 $\beta(70)$.

\section{CORONAVIRUSES AND INFLAMMATION}

The inflammatory response following $\mathrm{CoV}$ infection has an anti-viral and a pro-viral role. In regard to the anti-viral response, inflammation restricts viral replication and infection. However, inflammation plays a pro-viral role when it acts to release virions. Current understanding of SARS-CoV-2 infection indicates that the virus infects the cell through angiotensinconverting enzyme-2 (ACE2) receptors in host cells by binding to the $S$ glycoprotein. ACE2 is part of the renin-angiotensin system (RAS) and is involved in the regulation of blood pressure and fluid homeostasis (71).

Recently, Shao et al. demonstrated that ACE2 receptor stimulation results in NLRP3 inflammasome activation in podocytes; thus, leading to cell death. Interestingly, this effect did not affect blood pressure (72). However, whether SARS$\mathrm{CoV}-2$ binding through the $\mathrm{S}$ glycoprotein to ACE2 results in inflammasome activation has yet to be determined. In addition, binding of angiotensin II receptor 1 (AT1) also results in NLRP3 inflammasome activation (73).

Interestingly, bats that are known to be infected by several CoVs such as Ebola, MERS, SARS-Co-V, and potentially SARS$\mathrm{CoV}-2$ remain asymptomatic following infection even in the presence of high viral loads in blood and tissues (74). It has been suggested that COVID-19 was passed to humans by an intermediate host between bats and humans, similar to previous $\mathrm{CoV}$ infections that were transmitted to humans through camels (MERS) or civets (SARS-CoV). Nevertheless, the intermediate host for COVID-19 remains unknown. Recently, Ahn et al. showed that following infection with MERS-CoV, bats are able to fight $\mathrm{CoV}$ infections with lower levels of NLRP3 inflammasome activation when compared to humans, without affecting viral load (75). Therefore, the molecular mechanism employed by bats to limit the damaging effects of $\mathrm{CoV}$ infections should be explored to develop better interventions for the care of COVID19-positive patients.

\section{INFLAMMASOMES, ACUTE RESPIRATORY DISTRESS SYNDROME, AND PNEUMONIA}

Traditionally, acute lung injury (ALI) is defined by pulmonary infiltrates and edema present in the chest as determined by radiography procedures in the absence of left atrial hypertension, or a pulmonary wedge pressure lower than $18 \mathrm{mmHg}$ and an arterial oxygen to inspired oxygen fraction $\left(\mathrm{PaO}_{2} / \mathrm{FiO}_{2}\right)$ lower than $300 \mathrm{mmHg}$ (76). On the other hand, when the $\mathrm{PaO}_{2} / \mathrm{FiO}_{2}$ is below $200 \mathrm{mmHg}$ the ALI is referred to as ARDS (76). Hence, according to this definition ARDS is a more severe form of ALI. However, the modern definition of ARDS, eliminates the use of ALI for humans, and limits its use to animal studies. Moreover, this modern definition of ARDS divides ARDS into mild (300$200 \mathrm{mmHg}$ ), moderate (200-100 $\mathrm{mmHg}$ ) and severe (below 100 $\mathrm{mmHg}$ ) based on the Berlin definition (77).

More recently, ARDS has been stratified based on different phenotypes such as those that are physiologically derived, which separates patients according to the $\mathrm{PaO}_{2} / \mathrm{FiO}_{2}$ ratio, the pulmonary dead space, the ventilator ratio, and the driving pressure $(78,79)$. The clinically derived phenotype considers whether the etiology is direct (pulmonary origin) or indirect (extrapulmonary origin) $(78,79)$. The biologic phenotype relies on biomarkers associated with ARDS and considers whether there is a hypo or hyperinflammatory response, which can be used as a guide for potential therapies $(78,79)$. Examples 
of these inflammatory markers that are associated with the cytokine storm are IL-6, IL-8, IL-18, and TNF. In addition, other markers associated with ARDS are proteins of endothelial injury such as surfactant protein-D or coagulation-associated proteins such as plasminogen activator inhibitor-1 and protein C. Moreover, recently it has been shown that increased levels of IL-18 were consistent with increased mortality in sepsis-induced ARDS (80). Therefore, the hyperinflammatory phenotype is characterized by increased inflammation, less ventilator-free days, and increased mortality when compared to the hypoinflammatory phenotype $(81,82)$. Thus, supporting a strong role for the inflammatory response in ARDS that is capable of determining favorable or unfavorable outcomes depending on whether there is hyperinflammation or hypoinflammation. Finally, another phenotype that has been described is the omics derived phenotype which stratifies patients based on genomewide association and microRNA transcriptomic analysis $(78,79)$.

Of the well-known CoVs (HCoV-OC43, HCoV-NL63, HCoVHKU1, MERS-CoV, SARS-CoV, and SARS-CoV-2), SARS-CoV-2 has garnered especial attention due to the level of infectivity as well as lethality in vulnerable populations. The acute stage of $\mathrm{CoV}$ infections is characterized by infiltration of immune cells into lung tissue, whereas the post-acute stage is characterized by pulmonary fibrosis (83). COVID-19, like other CoV infections, causes ALI with high viral titers, high levels of the inflammatory cytokines IL- $1 \beta$ and IL- 6 as well as infiltration of macrophages and neutrophils into the lungs (84).

High mobility group box 1 protein (HMGB1), which activates the inflammasome in the lungs leading to ARDS/ALI (85), is upstream of IL-6 release (86), and has been suggested to play a key role in the inflammatory response occurring in the lungs of COVID-19 patients (87).

COVID-19 infections are associated with bacterial and viral pneumonia. Pneumonia following $\mathrm{CoV}$ infection can be either viral that may result in secondary bacterial pneumonia, or due to a combination of viral and bacterial pneumonia, However, the combined type has a lower incidence. Following SARS-CoV infection, secondary bacterial (methicillin-resistant Staphylococcus aureus) pneumonia has been described with ventilator-associated pneumonia (VAP) (88).

Although the role of the inflammasome in viral pneumonias has not been thoroughly examined, several studies point to inflammasome activation after bacterial infections by different organisms. For instance, NLRP3, ASC, and caspase-1 are upregulated following Streptococcus pneumoniae (S. pneumoniae) infection, resulting in production of IL-1 $\beta$ (89). The authors showed that NLRP3 knockout cells were able to produce IL-1 $\beta$. However, ASC knockouts significantly decreased the levels of IL-1 $\beta$ (89), pointing to the possibility that even if the NLRP3 inflammasome is blocked, other inflammasomes that require ASC may compensate for the role of NLRP3 such as the AIM2 inflammasome or other NLR-dependent inflammasomes, yet NLRP3 knockout mice are more susceptible to the effects of pneumococcal pneumonia infection than wild types. Moreover, levels of infiltrated leukocytes into the lungs was not affected by knockdown of NLRP3, but pulmonary edema did increase in the NLRP3 knockout mice as determined by decreased dynamic lung compliance, which probably explains why NLRP3 knockouts were more likely to die. However, a better measure of edema would have been the determination of the wet to dry lung ratio or BALF total protein.

Similarly, mice deficient in NLRP3 are also susceptible to the effects of $\alpha$-hemolysin-expressing Staphylococcus aureus ( $S$. aureus) in murine pneumonia and are able to produce IL-1 $\beta$, suggesting that other inflammasomes besides NLRP3 may be involved in the innate immune response to $\mathrm{S}$. aureus pneumonia (90). On the other hand, knocking out the NLRC4 inflammasome has been shown to be protective following Pseudomonas aeruginosa ( $P$. Aeruginosa) pneumonia as determined by improved bacterial clearance, decreased mortality and decreased lung damage (91). In this study, the authors suggested that the inflammasome may not be needed to fight the infection. However, the inflammasome seemed to play a role in increasing levels of IL-1 $\beta$ and IL-18, resulting in decreased bacterial clearance and increased lung toxicity. In contrast, during influenza A infection, the AIM2 inflammasome is activated, leading to lung injury and mortality (92). Moreover, in this study the authors showed that AIM2 knockout mice presented less ALI and increased survival without affecting viral load in the lungs (92).

\section{COVID-19, VENTILATOR SUPPORT, AND THE INFLAMMASOME}

Mechanical ventilation is used as a treatment for ARDS in order to expand collapsed alveoli. The high pressure generated by mechanical ventilation leads to VILI (93). VILI has been described in SARS (94) and COVID-19 (93). Wu et al. showed that this process was mediated in part by the NLRP3 inflammasome by sensing lung alveolar stretch (95), suggesting that stretch-injury in VILI activates an innate immune response that was partially mediated by the inflammasome. In addition, activation of the NLRP3 inflammasome by stretched injury seems to be regulated by an interaction between NEK-7 and NLRP3, which can be treated with glibenclamide (Glyburide) in mice (96).

Furthermore, a study by Dolinay and colleagues showed upregulation of $I l 1 b$ in a rodent model of VILI (97). The mRNA transcript levels of caspase-1, IL-1 $\beta$, and IL18 were higher in patients with sepsis/ARDS when compared to patients with systemic inflammatory response syndrome and controls (97). Moreover, deletion of IL-18 and caspase-1 were shown to be protective following VILI, and delivery of a neutralizing antibody against IL-18 resulted in decreased neutrophil counts in BALF (97).

Moreover, another complication associated with mechanical ventilation in COVID-19 patients is VAP $(98,99)$. In general, VAP takes place in $\sim 20 \%$ of patients who undergo mechanical ventilation for over $48 \mathrm{~h}$ (100), resulting in $\sim 30 \%$ mortality rate (101). Escherichia coli (E. coli), Klebsiella pneumoniae, P. aeruginosa, Acinetobacter baumannii, and $S$. aureus are the main causative organisms of VAP (102). Mortality in the intensive care unit associated with VAP is usually related to multi-drug resistant 
pathogens, and early diagnosis of VAP by proper identification of the causative agent is paramount to increase patient survival (98). In a study analyzing BALF and serum from 73 patients suspected to have VAP and 21 age-matched volunteer controls, it was found that IL- $1 \beta$ and IL-8 in BALF were higher in the VAP suspected cases when compared to controls (103).

\section{INFLAMMASOMES, CYTOKINE RELEASE SYNDROME, AND COVID-19}

It has been suggested that a major contributor to poor outcomes in patients with COVID-19 is an exacerbated immune response (104). This heightened immune response is characterized by unusually high levels of inflammatory cytokines such as IL-1 $\beta$ (the main cytokine activated by the inflammasome together with IL-18), IL-2, Monocyte Chemoattractant Protein-1 (MCP-1), macrophage inflammatory protein-1 $\alpha$ (MIP1A), IL-6, IL-7, IL-8, TNF, Granulocyte-macrophage colony-stimulating factor (GMCSF), CC-chemokine ligand 2 (CCL2), CCL3, CXC-chemokine ligand 10 (CXCL10), and the soluble form of the $\alpha$-chain of the IL-2 receptor, among others $(104,105)$. The exacerbated immune response is referred to as cytokine storm syndrome or cytokine release syndrome (CRS). However, despite the increased levels of a variety of cytokines in COVID-19 patients, those protein levels seem to be 10 to 40 times lower in COVID-19 patients than in patients with ARDS (106). Thus, CRS may not fully explain the poor outcomes experienced by COVID-19 patients and further investigation into the inflammatory response in these patients is granted.

The heightened inflammatory response in COVID-19 patients presents with decreased CD- $8^{+} \mathrm{T}$ cells in blood (lymphopenia) probably due to infiltration of these cells into tissues or due to a response to the steroid treatment given to these patients (104). In post-mortem studies, lymphocytic cell death has been detected in the lymph nodes and spleen, which could also explain the lymphopenia. CRS may result in hemophagocytic lymphohistiocytosis (HLH) or macrophage activation syndrome (MAS), leading to high fever, high levels of ferritin, and hypertriglyceridemia (107).

Symptoms of CRS range from mild to high fever, fatigue, headache, rash, arthralgia, myalgia, hypotension, circulatory shock, vascular leakage, DIC, and multi-organ dysfunction syndrome (MODS) (107). Patients with CRS also present with cytopenia, and elevated C-reactive protein (CRP), creatinine levels, liver enzymes, and D-Dimer values. Additionally, von Willebrand factor (VWF), a marker of endothelial activation is also increased in CRS and has been described in COVID19 patients (108). This suggests that endothelial cells may be an attractive therapeutic target for the treatment of COVID19-related hyperinflammation, especially in cases presenting capillary leakage, hypotension and coagulopathy.

IL- 6 is induced by IL- $1 \beta$, the main cytokine activated by the inflammasome (109). Therefore, inhibition of the inflammasome could be expected to help treat patients with CRS. IL-18, the other cytokine controlled by inflammasome activation is also elevated in patients with CRS (110). Since there is no FDA-approved drug that directly inhibits the inflammasome, to this extent, anti-IL6 and anti-IL- $1 \beta$ signaling therapies are being tested in patients with COVID-19 $(111,112)$. Increased IL-6 levels lead to vascular leakage, DIC and myocardial dysfunction (107).

In addition, type I IFN signaling has been reported to be decreased in patients with COVID-19 (113). It is possible that decreased type I IFN signaling in the presence of an exacerbated inflammatory response may be related to increased inflammasome signaling (114). However, viral infections are capable of generating high levels of type I IFN, and deletion of IFNAR1, a receptor involved in type I IFN signaling, or downstream type I IFN signaling pathways increases the replication, dissemination and lethality associated with viral infections (115), indicating that type I IFN are also involved in viral clearance.

In a mouse model of $S$. suis infection, Lin et al. studied the systemic effects of Streptococcal toxic-shock-like syndrome (STSLS) on cytokine production. STSLS is characterized by fever, blood spots (purpura), hypotension, shock and MODS, similar to what is seen in patients with CRS. In that study, the NLRP3 inflammasome was activated by $S$. suis leading to production of IL-1 $\beta$, resulting in CRS (116), further highlighting that the inflammasome is a contributor to the effects of CRS following infections. Thus, the cytokine storm results in MODS, which can severely affect patients by inducing an inflammatory response that spreads to other organs beyond the lungs. As a result, a concern in COVID-19 patients is not only what happens due to the pulmonary infection but also the non-respiratory manifestations associated with the inflammatory response caused by SARS-CoV-2 infections.

\section{THE INFLAMMASOME, COVID-19, AND NON-RESPIRATORY MANIFESTATIONS}

In addition to the respiratory effects associated with COVID-19, other manifestations affecting a variety of organ-systems have been recognized (Table 2).

\section{Cardiovascular Manifestations}

Patients with pre-existent cardiovascular conditions tend to have worse outcomes due to COVID-19 than patients who do not present a cardiovascular comorbidity, including hypertension. Due to the manifestation of a cardiovascular involvement in more severe cases, it is likely that the effects on the heart are due to sequelae associated with the CRS. Thus, a reduction and control of the cytokine storm may alleviate the deleterious effects in these patients. COVID-19 exacerbates underlying cardiovascular conditions such as ischemic heart disease and chronic heart failure (130). In addition, it may cause myocardial injury, myocarditis, arrhythmia, acute coronary syndrome, cardiogenic shock, stroke, venous thromboembolism, and pulmonary embolism (130).

Non-ischemic events in the heart, such as pressure overload, activate the inflammasome in the heart probably as a result of ROS production following stimulation of $\beta$-adrenergic receptors, resulting in higher levels of NLRP3 and ASC as well as 
TABLE 2 | Potential effects of inflammasome activation on COVID-19 manifestations.

\begin{tabular}{|c|c|c|}
\hline Manifestation & Effects & References \\
\hline Respiratory & $\begin{array}{l}\text { - HMGB1 activates the inflammasome leading to ARDS and ALI } \\
\text { - HMGB1 is upstream of IL-6 NLRP3, ASC and caspase-1 are upregulated following (S. pneumoniae) infection }\end{array}$ & $(85,86,88,89)$ \\
\hline Cardiovascular & $\begin{array}{l}\text { - Pressure overload, activates the inflammasome in the heart following stimulation of b-adrenergic receptors, } \\
\text { resulting in higher levels of NLRP3, ASC and IL-18 from myocardial cells } \\
\text { - Cardiac arrhythmias } \\
\text { - IL-1 } \beta \text { and IL-18 have been associated with hypertension }\end{array}$ & $(117-121)$ \\
\hline Gastrointestinal & $\begin{array}{l}\text { - Enteroviruses activate the inflammasome by acting on NLRP3, caspase-1, ASC, IL-1 } 13 \text { and GSDM-D } \\
\text { - Ionic imbalances associated with SARS-CoV-2 infections may activate the inflammasome } \\
\text { - NLRP3 inflammasome inhibition lowers ALT and AST levels, improving liver fibrosis } \\
\text { - Acute pancreatitis activates the NLRP3 inflammasome } \\
\text { - The gut-lung axis communicates the lungs with the Gl system }\end{array}$ & $(122-125)$ \\
\hline Neurological & - The brain-lung axis communicates the lungs with the brain through EV containing inflammasome proteins & $(126)$ \\
\hline Ophthalmic & $\begin{array}{l}\text { - In conjunctival goblet cells, infections activate the NLRP3 inflammasome } \\
\text { - In conjunctival goblet cells, infections activate the purinergic receptors P2X4 and P2X7 } \\
\text { - The NLRC4 inflammasome is activated in corneal ulcers }\end{array}$ & $(127,128)$ \\
\hline Renal & - Zika virus induces AKI through NLRP3 inflammasome & $(129)$ \\
\hline
\end{tabular}

production of IL-18 from myocardial cells (117). Similarly the inflammasome was shown to be involved in cardiac arrhythmias (118), and higher levels of IL-1 $\beta$ and IL-18 have been associated with hypertension (119). In a mouse model of hypertension, the inflammasome is activated in the kidneys, resulting in production of IL-1 $\beta$ but not IL-18 (120); whereas inhibition of the inflammasome resulted in lower blood pressure (121).

Taken together, considering the exacerbated inflammatory response that COVID-19 patients present, the effects of the inflammasome on the cardiovascular system could explain, in part, some of the adverse cardiovascular events seen with COVID-19; however, a direct role between inflammasomes and cardiac complications has not been tested in an animal model of $\mathrm{CoV}$ infections.

\section{Gastrointestinal Manifestations}

Problems with the gastrointestinal system such as diarrhea, abdominal pain, vomiting and lack of appetite have been described in COVID-19 patients. In some cases, these symptoms occur even in the absence of any respiratory symptoms, and sometimes correspond to a longer time between disease onset and hospitalization when compared to patients who do not present any digestive symptoms (131). Lack of appetite may be associated with the anosmia that characterizes some of the symptoms experienced by some patients. However, the cause of digestive symptoms in some COVID-19 cases is not well-understood, yet it is possible that the effects are due to an alteration of the intestinal microbiome by the infection, or the result of the effects of the virus binding to the liver, which expresses ACE2 receptors. Accordingly, Pan et al. suggest that an alteration in the gut-lung axis (122) may be responsible for the digestive symptoms in some COVID-19 patients, which could also explain how a problem affecting the lungs also affects the gastrointestinal system (131).

Similar to CoVs, enteroviruses are also positive-sense single stranded RNA viruses, and several enteroviruses have been shown to activate the inflammasome by acting on NLRP3, caspase-1, ASC, IL-1 $\beta$, and GSDM-D (123), indicating that the inflammasome can be activated by infections that affect the gastrointestinal system, and that the machinery responsible for the inflammatory response mediated by the inflammasome is present in the gastrointestinal system. However, whether CoVs activate the inflammasome directly in the gastrointestinal tract is yet to be determined. It is possible that the ionic imbalances associated with SARS-CoV-2 infections also results in inflammasome activation in the gut (132), Moreover, there is ample evidence on inflammasome regulation of the inflammatory response in intestines in chronic diseases like Chron's disease and colitis (133), further highlighting the relevance of this innate immune complex in inflammatory events in the gastrointestinal tract.

In the liver, COVID-19 increases the levels of alanine aminotransferase (ALT) and aspartate aminotransferase (AST), particularly in severe cases (134). Although no-link between inflammasome and liver problems have been described following $\mathrm{CoV}$ infections, previous studies have shown that inhibition of the NLRP3 inflammasome lowers the levels of ALT and AST, improving outcomes in liver fibrosis and nonalcoholic steatohepatitis (NASH) in mice (124), suggesting that inflammasome inhibition may be beneficial to control the effects caused by CoVs infections in the liver.

The pancreas also expresses ACE2 receptors, making the pancreas a target for $\mathrm{CoV}$ infections. Previously, SARS-CoV was shown to damage pancreatic islet cells leading to diabetes (135). Furthermore, following COVID-19, there is an association between poorer outcomes and diabetes. However, poorer outcomes in diabetics seemed to be less frequent in older individuals and those with hypertension (136). However, the mechanism for this finding is presently unknown. It is possible that medications used to treat these patients also might serve to treat some of the symptoms associated with COVID-19, including hyperactivation of the immune response.

In addition, NLRP3 inflammasome proteins are elevated in monocyte-derived macrophages and peripheral blood mononuclear cells from patients with diabetes (137). Acute 
pancreatitis, which has been described in COVD-19 patients and is worse in diabetics, also activates the NLRP3 inflammasome (125). Thus, a heightened inflammatory response in patients with diabetes could be a risk factor in patients with diabetes and COVID-19.

\section{Neurological Manifestations}

Cerebrovascular complications, convulsions, encephalitis, change in mental status, confusion, headaches and febrile seizures as well as taste (hypogeusia/ageusia) and smell (anosmia/hyposmia) dysfunction have been described in patients with COVID-19 $(138,139)$. Although, the mechanism of taste and smell dysfunction is not known, it is possible that the virus binds to ACE2 in the oral mucosa (140), affecting this sensing function. Although smell and taste dysfunction are common in several upper respiratory infections, it seems that in COVID-19, these are even more prevalent (141).

Moreover, CoVs have been detected in the cerebrospinal fluid (CSF) of patients with SARS-CoV (142), suggesting the possibility of a similar neurological involvement in patients with COVID-19. In addition, SARS-CoV-2 has been shown to affect human neural progenitor cells and brain organoids (143), indicating the possibility of direct infection by $\mathrm{CoV}$ in brain tissue. Inflammasomes have been shown to be activated in a variety of diseases and injuries affecting the CNS (25, 28-30). Thus, the CNS is capable of mounting an immune response through the inflammasome. Recently a mechanism was described by which inflammasome proteins are carried in extracellular vesicles (EV) to the lungs from the brain following brain injury, thus inducing ALI (126). Therefore, it is also possible that the lung secretes inflammasome proteins in extracellular vesicles that are carried to the CNS following infection, causing neurological symptoms. Although EV are capable of carrying viral components (144), whether EV are secreted during COVID-19 as part of the neuro-respiratory lung axis is yet to be determined.

\section{Ophthalmic Manifestations}

Studies indicate that patients with severe COVID-19 may present conjunctivitis (145), and CoVs have been previously detected in tears (146). CoVs gain direct access to the conjunctival mucosa as the viral particles from an infected patient travel in droplets that reach the eye. However, how $\mathrm{CoV}$ reach the tear film in the absence of direct access from the virus to the conjunctival mucosa is yet to be fully elucidated. Evidence from feline $\mathrm{CoV}$ suggests that infected macrophages and monocytes extravasate immune tissues and cause endothelial cell dysfunction that leads to vasculitis (147). It is the vasculitis that is believed to be an underlying contributor to the ocular manifestations seen following feline $\mathrm{CoV}$ infections, which include conjunctivitis, retinal vasculitis, pyogranulomatous anterior uveitis and choroiditis with retinal detachment (148). In addition, in mouse CoV, inflammation in the eye results in optic neuritis and retinal degeneration that affects photoreceptors and ganglion cells (149).

Although conjunctivitis remains the only ocular manifestation widely reported in regards to COVID-19, it is possible that

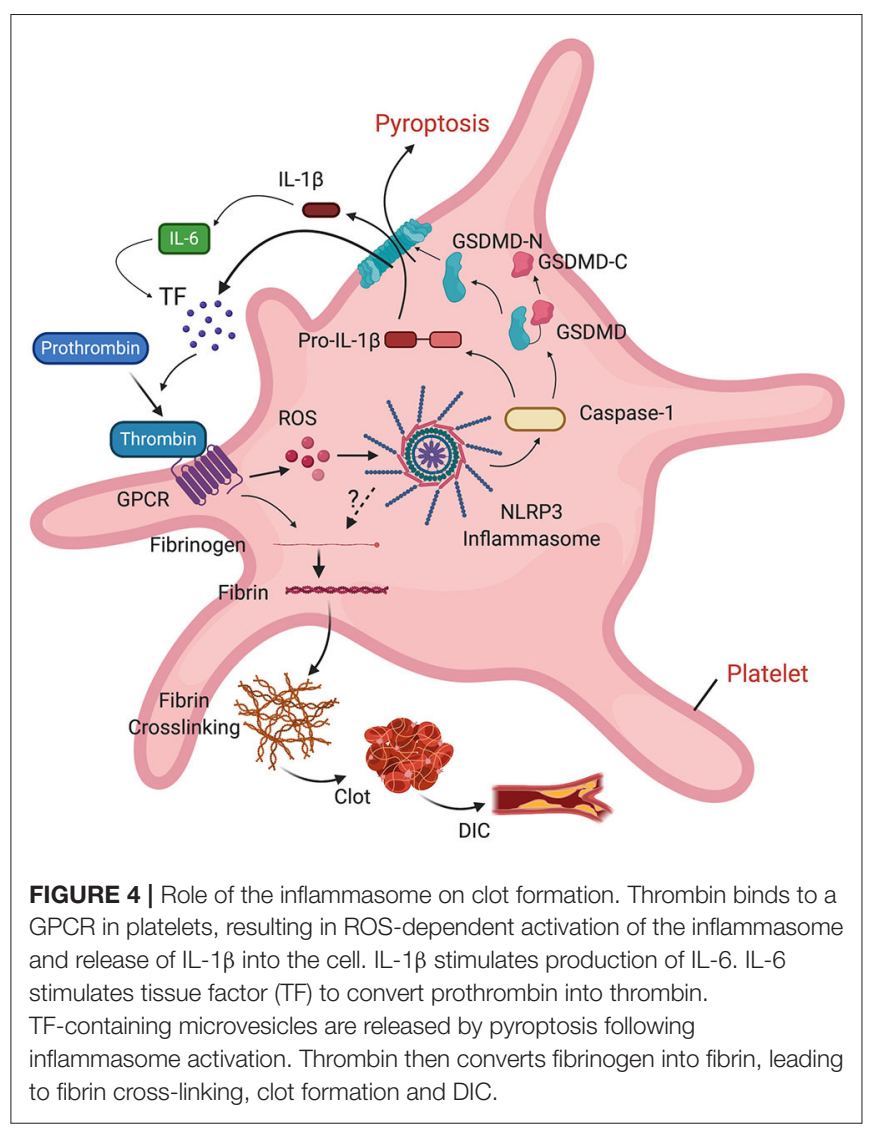

other conditions may arise upon closer examination of COVID19 patients.

Moreover, in goblet cells of the conjunctiva S. aureus activates the NLRP3 inflammasome as well as the purinergic receptors $\mathrm{P} 2 \mathrm{X} 4$ and $\mathrm{P} 2 \mathrm{X} 7$ which have been shown to be involved in inflammasome signaling $(49,127,150)$. In addition, S. pneumoniae and P. aeruginosa activate the NLRC4 inflammasome in corneal ulcers (128). Thus, the ocular surface has the inflammasome machinery necessary to mount an innate immune response against conjunctivitis in the presence of COVID-19. However, further studies are needed to understand the type of conjunctivitis present in COVID-19 patients.

\section{Renal Manifestations}

Acute kidney injury (AKI) is a significant problem in patients with COVID-19 (151). Patients develop AKI during hospital admission and when disease is severe, such as in patients with ARDS or on mechanical ventilation, as well as in patients with hypertension or diabetes (151). It is possible that in COVID-19, the exacerbated inflammatory response or vascular thrombosis can damage the kidneys. In addition, ACE2 receptors are present in the kidney, making this organ a potential direct target of SARSCoV-2 infection. A potential contributor to the exacerbated inflammatory response is the inflammasome that besides being involved in CRS, it is present in the kidneys where it contributes to inflammation in several renal diseases and complications, 
TABLE 3 | Potential therapies targeting the inflammasome that could be used in the care of COVID-19 patients.

\begin{tabular}{|c|c|c|}
\hline Therapy & Mechanism of action & References \\
\hline Dexamethasone & Decreases airway inflammation by inhibiting NLRP3 inflammasome activation and levels of IL-1 $\beta$ and IL-18 & $(159,160)$ \\
\hline Enoxaparin & Low molecular weight heparin shown to inhibit inflammasome activation in a mouse model of brain injury-induced ALI. & $(161,162)$ \\
\hline IFN- $\beta$ & Type I IFNs decreased NLRP3 inflammasome activation through STAT1 & $(163,164)$ \\
\hline MCC950 & Inhibits inflammasome activation by preventing NLRP3 oligomerization & $(158)$ \\
\hline IC100 & Inhibits inflammasome activation by preventing ASC-speck formation & (25) \\
\hline M5049 & Inhibits TLR7 and TLR8, which have been described in Inflammasome activation & $(165-167)$ \\
\hline Anakinra & IL-1 receptor blocker & $(168)$ \\
\hline Tocilizumab & Therapeutic monoclonal antibody that blocks IL-6 signaling & $(168)$ \\
\hline
\end{tabular}

including AKI (152). Previously, the zika virus has been shown to induce AKI through NLRP3 inflammasome activation (129); however, whether SARS-CoV-2 is responsible for inducing AKI through the inflammasome in COVID-19 has yet to be tested.

\section{INFLAMMASOME AND DISSEMINATED INTRAVASCULAR COAGULATION (DIC)}

Severe cases of COVID-19 may present with coagulation complications that manifest as thrombi, high levels of D-dimers (a sign of fibrin degradation), prolonged prothrombin time, and low platelet count (thrombocytopenia) that may lead to DIC. Thrombi in COVID-19 patients have been described in the lungs, heart, brain, liver, kidneys and lower limbs (104). DIC tends to present in cases of sepsis where it blocks microvessels and leads to organ dysfunction.

In addition to DIC, some patients with COVID-19 may present pulmonary embolism (153) and deep vein thrombosis (154). The NLRP3 inflammasome has been described as a signaling intermediate between inflammation and thrombosis by modulating clot retraction and platelet spreading (155). NLRP3 knockout mice present abnormal hemostasis and arterial thrombosis, probably as part of a mechanism that involves binding of thrombin to G protein-coupled receptors (GPCR), which stimulates ROS production in platelets. ROS activates the inflammasome, resulting in IL- $1 \beta$ signaling that is followed by platelet spreading and clot retraction (155). IL-6 stimulates tissue factor (TF) to transform prothrombin into thrombin. Thrombin then converts fibrinogen into the fibrin that is characteristic of thrombi. Thus, there is a clear association between the inflammasome and clot formation. Furthermore, inflammasome activation causes release of microvesicles containing TF by pyroptosis, resulting in systemic coagulation and death (156), which provides a mechanism by which DIC may contribute to the poor outcomes experienced by COVID-19 patients (Figure 4).

\section{CONCLUSIONS}

To date, therapies intended to treat COVID-19 include Remdesivir or Favipiravir to control translational replication of viral RNA, Tocilizumab to block the IL-6 receptor, Bevacizumab to block vascular endothelial growth factor
(VEGF), Anakinra to block IL-1 receptor activity, Lopinavir or Ritonavir to target proteolysis, Losartan to target ACE2 receptors, corticosteroids such as Dexamethasone to target the exacerbated inflammatory response, heparin to treat DIC and intravenous immunoglobulins to target CRS, or convalescent plasma, among others (157). Thus, great efforts are being undertaken to develop therapeutics against the pulmonary and systemic manifestations of COVID-19.

This review highlights the inflammasome as a target to interfere with different aspects associated with this pandemiccausing virus. However, care must be taken since inflammasome signaling may be necessary to fight the actual viral infection, while at the same time inflammasome activation may be responsible for the hyperactivated inflammatory response that leads to sepsis, DIC, AKI and death. Mechanisms employed by bats to dampen $\mathrm{CoV}$ infections indicate that inflammation signaling pathways are probably better targets than reduction of viral load in controlling COVID-19. Thus, a better understanding of the role of inflammasomes and inflammatory processes in CoVs and those regulating viral load are critical for development of therapeutics to treat these diseases, and although to date there are no FDA-approved drugs that directly target the inflammasome, in regards to inflammasome signaling and therapeutics that can be considered for COVID-19 treatment, potential therapies that are currently being manufactured for the treatment of inflammasome-related diseases include MCC950 that interferes with NLRP3 inflammasome activation by binding to the NACHT domain of NRLP3, hence preventing its oligomerization (158), as well as IC100, a monoclonal antibody with intracellular and extracellular action that interferes with ASC speck formation (25) (Table 3).

On the other hand, there are some therapies that are already FDA-approved and have been shown to interfere with inflammasome signaling activation which are already being considered for the treatment of COVID-19 such as Enoxaparin (161, 162), anakinra (168), tocilizumab (168), and dexamethasone $(159,160)$. Moreover, another drug that is already approved by the FDA that can also be used to inhibit the inflammasome is IFN- $\beta$ (163), which is already used to treat multiple sclerosis (169), and is currently being tested for its effects on COVID-19 patients (164).

Moreover, TLR7 and TLR8, which have been implicated in inflammasome signaling (165) have been suggested to play 
an underlying role in COVID-19 severity (166). TLR7/8 are activated by single stranded RNA viruses like SARS-CoV-2, and in addition to their role on inflammasome activation (165), these PRR are better known for their involvement in type I IFN synthesis and a variety of IFN stimulated genes (ISG), which when deregulated are capable of contributing to an exacerbated inflammatory immune response (167). As a result, M5049, a TLR7/8 inhibitor, is currently being tested in clinical trials for the treatment of severe symptoms of COVID-19 as a potential treatment for CRS (167) (Table 3).

Given the number of people that have been affected with COVID-19 worldwide, a better understanding of the systemic effects associated with COVID-19 during and after infection resolution is of paramount importance, and given the possibility that $\mathrm{CoV}$ infections may become a seasonal infection similar to influenza virus infections, it remains critical to identify FDA-approved and future novel therapeutics that can be

\section{REFERENCES}

1. Enjuanes L, Dediego ML, Alvarez E, Deming D, Sheahan T, Baric R. Vaccines to prevent severe acute respiratory syndrome coronavirus-induced disease. Virus Res. (2008) 133:45-62. doi: 10.1016/j.virusres.2007.01.021

2. Wong SK, Li W, Moore MJ, Choe H, Farzan M. A 193-amino acid fragment of the SARS coronavirus S protein efficiently binds angiotensin-converting enzyme 2. J Biol Chem. (2004) 279:3197-201. doi: 10.1074/jbc.C300520200

3. Nguyen VP, Hogue BG. Protein interactions during coronavirus assembly. $J$ Virol. (1997) 71:9278-84. doi: 10.1128/JVI.71.12.9278-9284.1997

4. Ruch TR, Machamer CE. The coronavirus E protein: assembly and beyond. Viruses. (2012) 4:363-82. doi: 10.3390/v4030363

5. Hasan A, Paray BA, Hussain A, Qadir FA, Attar F, Aziz FM, et al. A review on the cleavage priming of the spike protein on coronavirus by angiotensin-converting enzyme-2 and furin. J Biomol Struct Dyn. (2020). doi: 10.1080/07391102.2020.1754293. [Epub ahead of print].

6. Drosten C, Gunther S, Preiser W, van Der Werf S, Brodt HR, Becker S, et al. Identification of a novel coronavirus in patients with severe acute respiratory syndrome. N Engl J Med. (2003) 348:1967-76. doi: 10.1056/NEJMoa 030747

7. Rota PA, Oberste MS, Monroe SS, Nix WA, Campagnoli R, Icenogle JP, et al. Characterization of a novel coronavirus associated with severe acute respiratory syndrome. Science. (2003) 300:1394-9. doi: $10.1126 /$ science. 1085952

8. Decaro N, Lorusso A. Novel human coronavirus. (SARS-CoV-2): a lesson from animal coronaviruses. Vet Microbiol. (2020) 244:108693. doi: 10.1016/j.vetmic.2020.108693

9. Martinon F, Burns K, Tschopp J. The inflammasome: a molecular platform triggering activation of inflammatory caspases and processing of proIL-beta. Mol Cell. (2002) 10:417-26. doi: 10.1016/S1097-2765(02)00599-3

10. De Rivero Vaccari JP, Dietrich WD, Keane RW. Activation and regulation of cellular inflammasomes: gaps in our knowledge for central nervous system injury. J Cereb Blood Flow Metab. (2014) 34:369-75. doi: $10.1038 /$ jcbfm.2013.227

11. He WT, Wan H, Hu L, Chen P, Wang X, Huang Z, et al. Gasdermin D is an executor of pyroptosis and required for interleukin-1beta secretion. Cell Res. (2015) 25:1285-98. doi: 10.1038/cr.2015.139

12. Chen X, He WT, Hu L, Li J, Fang Y, Wang X, et al. Pyroptosis is driven by non-selective gasdermin-D pore and its morphology is different from MLKL channel-mediated necroptosis. Cell Res. (2016) 26:1007-20. doi: $10.1038 / \mathrm{cr} .2016 .100$

13. Johnston JB, Barrett JW, Nazarian SH, Goodwin M, Ricciuto D, Wang G, et al. A poxvirus-encoded pyrin domain protein interacts with ASC-1 to used for the treatment of $\mathrm{CoV}$ infections and the associated systemic manifestations.

\section{AUTHOR CONTRIBUTIONS}

JPdRV and JCdRV designed the structure of the review and performed the literature search. All authors contributed to the writing of this article.

\section{FUNDING}

This work was funded by an R01 grant from the NIH/NINDS to RWK and JPdRV (R01NS113969-01).

\section{ACKNOWLEDGMENTS}

Figures in this manuscript were created using BioRender.com. inhibit host inflammatory and apoptotic responses to infection. Immunity. (2005) 23:587-98. doi: 10.1016/j.immuni.2005.10.003

14. Hise AG, Tomalka J, Ganesan S, Patel K, Hall BA, Brown GD, et al. An essential role for the NLRP3 inflammasome in host defense against the human fungal pathogen Candida albicans. Cell Host Microbe. (2009) 5:48797. doi: 10.1016/j.chom.2009.05.002

15. Agostini L, Martinon F, Burns K, Mcdermott MF, Hawkins PN, Tschopp J. NALP3 forms an IL-1beta-processing inflammasome with increased activity in Muckle-wells autoinflammatory disorder. Immunity. (2004) 20:319-25. doi: 10.1016/S1074-7613(04)00046-9

16. Kastbom A, Verma D, Eriksson P, Skogh T, Wingren G, Soderkvist P. Genetic variation in proteins of the cryopyrin inflammasome influences susceptibility and severity of rheumatoid arthritis. (the Swedish TIRA project). Rheumatology (Oxford). (2008) 47:415-7. doi: 10.1093/rheumatology/kem 372

17. Liu-Bryan R. Intracellular innate immunity in gouty arthritis: role of NALP3 inflammasome. Immunol Cell Biol. (2010) 88:20-3. doi: 10.1038/icb.2009.93

18. Masters SL, Dunne A, Subramanian SL, Hull RL, Tannahill GM, Sharp FA, et al. Activation of the NLRP3 inflammasome by islet amyloid polypeptide provides a mechanism for enhanced IL-1beta in type 2 diabetes. Nat Immunol. (2010) 11:897-904. doi: 10.1038/ni.1935

19. He J, Yang Y, Peng DQ. Monosodium urate. (MSU) crystals increase gout associated coronary heart disease. (CHD) risk through the activation of NLRP3 inflammasome. Int J Cardiol. (2012) 160:72-3. doi: 10.1016/j.ijcard.2012.05.083

20. Scarpioni R, Obici L. Renal involvement in autoinflammatory diseases and inflammasome-mediated chronic kidney damage. Clin Exp Rheumatol. (2018) 36(Suppl. 110):54-60.

21. Wan X, Xu C, Yu C, Li Y. Role of NLRP3 inflammasome in the progression of NAFLD to NASH. Can J Gastroenterol Hepatol. (2016) 2016:6489012. doi: $10.1155 / 2016 / 6489012$

22. Carlstrom M, Ekman AK, Petersson S, Soderkvist P, Enerback C. Genetic support for the role of the NLRP3 inflammasome in psoriasis susceptibility. Exp Dermatol. (2012) 21:932-7. doi: 10.1111/exd.12049

23. Levandowski CB, Mailloux CM, Ferrara TM, Gowan K, Ben S, Jin Y, et al. NLRP1 haplotypes associated with vitiligo and autoimmunity increase interleukin-1beta processing via the NLRP1 inflammasome. Proc Natl Acad Sci USA. (2013) 110:2952-6. doi: 10.1073/pnas.1222808110

24. Keane RW, Dietrich WD, De Rivero Vaccari JP. Inflammasome proteins as biomarkers of multiple sclerosis. Front Neurol. (2018) 9:135. doi: $10.3389 /$ fneur.2018.00135

25. Desu HL, Plastini M, Illiano P, Bramlett HM, Dietrich WD, De Rivero Vaccari JP, et al. IC100: a novel anti-ASC monoclonal antibody improves functional 
outcomes in an animal model of multiple sclerosis. J Neuroinflammation. (2020) 17:143. doi: 10.1186/s12974-020-01826-0

26. Scott XO, Stephens ME, Desir MC, Dietrich WD, Keane RW, De Rivero Vaccari JP. The inflammasome adaptor protein ASC in mild cognitive impairment and Alzheimer's disease. Int J Mol Sci. (2020) 21:4674. doi: $10.3390 / \mathrm{ijms} 21134674$

27. Zhou Y, Lu M, Du RH, Qiao C, Jiang CY, Zhang KZ, et al. MicroRNA7 targets Nod-like receptor protein 3 inflammasome to modulate neuroinflammation in the pathogenesis of Parkinson's disease. Mol Neurodegener. (2016) 11:28. doi: 10.1186/s13024-016-0094-3

28. De Rivero Vaccari JP, Lotocki G, Marcillo AE, Dietrich WD, Keane RW. A molecular platform in neurons regulates inflammation after spinal cord injury. J Neurosci. (2008) 28:3404-14. doi: 10.1523/JNEUROSCI.0157-08.2008

29. Abulafia DP, De Rivero Vaccari JP, Lozano JD, Lotocki G, Keane RW, Dietrich WD. Inhibition of the inflammasome complex reduces the inflammatory response after thromboembolic stroke in mice. J Cereb Blood Flow Metab. (2009) 29:534-44. doi: 10.1038/jcbfm.2008.143

30. De Rivero Vaccari JP, Lotocki G, Alonso OF, Bramlett HM, Dietrich WD, Keane RW. Therapeutic neutralization of the NLRP1 inflammasome reduces the innate immune response and improves histopathology after traumatic brain injury. J Cereb Blood Flow Metab. (2009) 29:1251-61. doi: $10.1038 / \mathrm{jcbfm} .2009 .46$

31. De Rivero Vaccari JP, Dietrich WD, Keane RW. Therapeutics targeting the inflammasome after central nervous system injury. Transl Res. (2016) 167:35-45. doi: 10.1016/j.trsl.2015.05.003

32. Ichinohe $\mathrm{T}$, Lee HK, Ogura $\mathrm{Y}$, Flavell R, Iwasaki A. Inflammasome recognition of influenza virus is essential for adaptive immune responses. J Exp Med. (2009) 206:79-87. doi: 10.1084/jem.20081667

33. Rajan JV, Rodriguez D, Miao EA, Aderem A. The NLRP3 inflammasome detects encephalomyocarditis virus and vesicular stomatitis virus infection. J Virol. (2011) 85:4167-72. doi: 10.1128/JVI.01687-10

34. Burdette D, Haskett A, Presser L, Mcrae S, Iqbal J, Waris G. Hepatitis $C$ virus activates interleukin-1beta via caspase-1-inflammasome complex. $J$ Gen Virol. (2012) 93:235-46. doi: 10.1099/vir.0.034033-0

35. Segovia J, Sabbah A, Mgbemena V, Tsai SY, Chang TH, Berton MT, et al. TLR2/MyD88/NF-kappaB pathway, reactive oxygen species, potassium efflux activates NLRP3/ASC inflammasome during respiratory syncytial virus infection. PLoS ONE. (2012) 7:e29695. doi: 10.1371/journal.pone.0029695

36. Kumar M, Roe K, Orillo B, Muruve DA, Nerurkar VR, Gale M Jr, et al. Inflammasome adaptor protein Apoptosis-associated speck-like protein containing CARD. (ASC) is critical for the immune response and survival in west Nile virus encephalitis. J Virol. (2013) 87:3655-67. doi: 10.1128/JVI.02667-12

37. Tricarico PM, Caracciolo I, Crovella S, D'agaro P. Zika virus induces inflammasome activation in the glial cell line U87-MG. Biochem Biophys Res Commun. (2017) 492:597-602. doi: 10.1016/j.bbrc.2017.01.158

38. Fan S, Yuan J, Deng S, Chen Y, Xie B, Wu K, et al. Activation of interleukinlbeta release by the classical swine fever virus is dependent on the NLRP3 inflammasome, which affects virus growth in monocytes. Front Cell Infect Microbiol. (2018) 8:225. doi: 10.3389/fcimb.2018.00225

39. Halfmann P, Hill-Batorski L, Kawaoka Y. The induction of IL-1beta secretion through the NLRP3 inflammasome during Ebola virus infection. J Infect Dis. (2018) 218:S504-7. doi: 10.1093/infdis/jiy433

40. Jia X, Liu B, Bao L, Lv Q, Li F, Li H, et al. Delayed oseltamivir plus sirolimus treatment attenuates H1N1 virus-induced severe lung injury correlated with repressed NLRP3 inflammasome activation and inflammatory cell infiltration. PLoS Pathog. (2018) 14:e1007428. doi: 10.1371/journal.ppat.1007428

41. Komatsu T, Tanaka Y, Kitagawa Y, Koide N, Naiki Y, Morita N, et al. Sendai virus $\mathrm{V}$ protein inhibits the secretion of interleukin-1beta by preventing NLRP3 inflammasome assembly. J Virol. (2018) 92:e00842-18. doi: 10.1128/JVI.00842-18

42. Maruzuru Y, Ichinohe T, Sato R, Miyake K, Okano T, Suzuki T, et al. Herpes simplex virus 1 VP22 inhibits AIM2-dependent inflammasome activation to enable efficient viral replication. Cell Host Microbe. (2018) 23:254-65.e7. doi: $10.1016 /$ j.chom.2017.12.014
43. De Carvalho RVH, Lima-Junior DS, Da Silva MVG, Dilucca M, Rodrigues TS, Horta CV, et al. Leishmania RNA virus exacerbates Leishmaniasis by subverting innate immunity via TLR3-mediated NLRP3 inflammasome inhibition. Nat Commun. (2019) 10:5273. doi: 10.1038/s41467-019-13356-2

44. Khan RA, Afroz S, Minhas G, Battu S, Khan N. Dengue virus envelope protein domain III induces pro-inflammatory signature and triggers activation of inflammasome. Cytokine. (2019) 123:154780. doi: 10.1016/j.cyto.2019.154780

45. Rawat P, Teodorof-Diedrich C, Spector SA. Human immunodeficiency virus Type-1 single-stranded RNA activates the NLRP3 inflammasome and impairs autophagic clearance of damaged mitochondria in human microglia. Glia. (2019) 67:802-24. doi: 10.1002/glia.23568

46. Nieto-Torres JL, Verdia-Baguena C, Jimenez-Guardeno JM, Regla-Nava JA, Castano-Rodriguez C, Fernandez-Delgado R, et al. Severe acute respiratory syndrome coronavirus $\mathrm{E}$ protein transports calcium ions and activates the NLRP3 inflammasome. Virology. (2015) 485:330-9. doi: 10.1016/j.virol.2015.08.010

47. Kigerl KA, de Rivero Vaccari JP, Dietrich WD, Popovich PG, Keane RW. Pattern recognition receptors and central nervous system repair. Exp Neurol. (2014) 258:5-16. doi: 10.1016/j.expneurol.2014.01.001

48. De Vasconcelos NM, Lamkanfi M. Recent insights on inflammasomes, gasdermin pores, and pyroptosis. Cold Spring Harb Perspect Biol. (2020) 12:a036392. doi: 10.1101/cshperspect.a036392

49. Silverman WR, De Rivero Vaccari JP, Locovei S, Qiu F, Carlsson SK, Scemes $\mathrm{E}$, et al. The pannexin 1 channel activates the inflammasome in neurons and astrocytes. J Biol Chem. (2009) 284:18143-51. doi: 10.1074/jbc.M109.004804

50. Latz E, Xiao TS, Stutz A. Activation and regulation of the inflammasomes. Nat Rev Immunol. (2013) 13:397-411. doi: 10.1038/nri3452

51. Netland J, Dediego ML, Zhao J, Fett C, Alvarez E, Nieto-Torres JL, et al. Immunization with an attenuated severe acute respiratory syndrome coronavirus deleted in E protein protects against lethal respiratory disease. Virology. (2010) 399:120-8. doi: 10.1016/j.virol.2010.01.004

52. Nieto-Torres JL, Dediego ML, Verdia-Baguena C, Jimenez-Guardeno JM, Regla-Nava JA, Fernandez-Delgado R, et al. Severe acute respiratory syndrome coronavirus envelope protein ion channel activity promotes virus fitness and pathogenesis. PLoS Pathog. (2014) 10:e1004077. doi: 10.1371/journal.ppat.1004077

53. Chen IY, Moriyama M, Chang MF, Ichinohe T. Severe acute respiratory syndrome coronavirus viroporin 3a activates the NLRP3 inflammasome. Front Microbiol. (2019) 10:50. doi: 10.3389/fmicb.2019.00050

54. Siu KL, Yuen KS, Castano-Rodriguez C, Ye ZW, Yeung ML, Fung SY, et al. Severe acute respiratory syndrome coronavirus ORF3a protein activates the NLRP3 inflammasome by promoting TRAF3-dependent ubiquitination of ASC. FASEB J. (2019) 33:8865-77. doi: 10.1096/fj.201802418R

55. Shi CS, Nabar NR, Huang NN, Kehrl JH. SARS-coronavirus open reading frame-8b triggers intracellular stress pathways and activates NLRP3 inflammasomes. Cell Death Discov. (2019) 5:101. doi: 10.1038/s41420-019-0181-7

56. Verdia-Baguena C, Nieto-Torres JL, Alcaraz A, Dediego ML, Torres J, Aguilella VM, et al. Coronavirus E protein forms ion channels with functionally and structurally-involved membrane lipids. Virology. (2012) 432:485-94. doi: 10.1016/j.virol.2012.07.005

57. Matthay MA, Zemans RL. The acute respiratory distress syndrome: pathogenesis and treatment. Annu Rev Pathol. (2011) 6:147-63. doi: 10.1146/annurev-pathol-011110-130158

58. Graham RL, Donaldson EF, Baric RS. A decade after SARS: strategies for controlling emerging coronaviruses. Nat Rev Microbiol. (2013) 11:836-48. doi: 10.1038/nrmicro3143

59. Meduri GU, Headley S, Kohler G, Stentz F, Tolley E, Umberger R, et al. Persistent elevation of inflammatory cytokines predicts a poor outcome in ARDS. Plasma IL-1 beta and IL-6 levels are consistent and efficient predictors of outcome over time. Chest. (1995) 107:1062-73. doi: 10.1378/chest.107.4.1062

60. Chien TH, Chiang YL, Chen CP, Henklein P, Hanel K, Hwang IS, et al. Assembling an ion channel: ORF 3a from SARS-CoV. Biopolymers. (2013) 99:628-35. doi: 10.1002/bip.22230

61. Venegas C, Kumar S, Franklin BS, Dierkes T, Brinkschulte R, Tejera $D$, et al. Microglia-derived ASC specks cross-seed amyloid-beta in 
Alzheimer's disease. Nature. (2017) 552:355-61. doi: 10.1038/nature 25158

62. Ichinohe T, Pang IK, Iwasaki A. Influenza virus activates inflammasomes via its intracellular M2 ion channel. Nat Immunol. (2010) 11:404-10. doi: $10.1038 /$ ni.1861

63. Ito M, Yanagi Y, Ichinohe T. Encephalomyocarditis virus viroporin 2B activates NLRP3 inflammasome. PLoS Pathog. (2012) 8:e1002857. doi: 10.1371 /journal.ppat.1002857

64. Triantafilou K, Triantafilou M. Ion flux in the lung: virus-induced inflammasome activation. Trends Microbiol. (2014) 22:580-8. doi: 10.1016/j.tim.2014.06.002

65. Chang YS, Ko BH, Ju JC, Chang HH, Huang SH, Lin CW. SARS Unique Domain. (SUD) of severe acute respiratory syndrome coronavirus induces NLRP3 inflammasome-dependent CXCL10-mediated pulmonary inflammation. Int J Mol Sci. (2020) 21:3179. doi: 10.3390/ijms21093179

66. Zalinger ZB, Elliott R, Weiss SR. Role of the inflammasome-related cytokines Il-1 and Il-18 during infection with murine coronavirus. J Neurovirol. (2017) 23:845-54. doi: 10.1007/s13365-017-0574-4

67. Allen IC, Scull MA, Moore CB, Holl EK, Mcelvania-Tekippe E, Taxman DJ, et al. The NLRP3 inflammasome mediates in vivo innate immunity to influenza A virus through recognition of viral RNA. Immunity. (2009) 30:556-65. doi: 10.1016/j.immuni.2009.02.005

68. Niu J, Wu S, Chen M, Xu K, Guo Q, Lu A, et al. Hyperactivation of the NLRP3 inflammasome protects mice against influenza A virus infection via IL-1beta mediated neutrophil recruitment. Cytokine. (2019) 120:115-24. doi: 10.1016/j.cyto.2019.04.019

69. Marsden PA, Ning Q, Fung LS, Luo X, Chen Y, Mendicino M, et al. The Fgl2/fibroleukin prothrombinase contributes to immunologically mediated thrombosis in experimental and human viral hepatitis. J Clin Invest. (2003) 112:58-66. doi: 10.1172/JCI18114

70. Guo S, Yang C, Diao B, Huang X, Jin M, Chen L, et al. The NLRP3 inflammasome and IL-1beta accelerate immunologically mediated pathology in experimental viral fulminant hepatitis. PLoS Pathog. (2015) 11:e1005155. doi: 10.1371/journal.ppat.1005155

71. Li XC, Zhang J, Zhuo JL. The vasoprotective axes of the reninangiotensin system: physiological relevance and therapeutic implications in cardiovascular, hypertensive and kidney diseases. Pharmacol Res. (2017) 125:21-38. doi: 10.1016/j.phrs.2017.06.005

72. Zhao M, Bai M, Ding G, Zhang Y, Huang S, Jia Z, et al. Angiotensin II stimulates the NLRP3 inflammasome to induce podocyte injury and mitochondrial dysfunction. Kidney Dis (Basel). (2018) 4:83-94. doi: $10.1159 / 000488242$

73. Ratajczak MZ, Kucia M. SARS-CoV-2 infection and overactivation of Nlrp3 inflammasome as a trigger of cytokine "storm" and risk factor for damage of hematopoietic stem cells. Leukemia. (2020) 34:1726-9. doi: 10.1038/s41375-020-0887-9

74. Watanabe S, Masangkay JS, Nagata N, Morikawa S, Mizutani T, Fukushi S, et al. Bat coronaviruses and experimental infection of bats, the Philippines. Emerg Infect Dis. (2010) 16:1217-23. doi: 10.3201/eid1608.100208

75. Ahn M, Anderson DE, Zhang Q, Tan CW, Lim BL, Luko K, et al. Dampened NLRP3-mediated inflammation in bats and implications for a special viral reservoir host. Nat Microbiol. (2019) 4:789-99. doi: 10.1038/s41564-019-0371-3

76. Bernard GR, Artigas A, Brigham KL, Carlet J, Falke K, Hudson L, et al. The American-European Consensus Conference on ARDS. definitions, mechanisms, relevant outcomes, and clinical trial coordination. Am J Respir Crit Care Med. (1994) 149:818-24. doi: 10.1164/ajrccm.149.3.7509706

77. Force ADT, Ranieri VM, Rubenfeld GD, Thompson BT, Ferguson ND, Caldwell E, et al. Acute respiratory distress syndrome: the Berlin definition. JAMA. (2012) 307:2526-33. doi: 10.1001/jama.2012.5669

78. Sinha P, Calfee CS. Phenotypes in acute respiratory distress syndrome: moving towards precision medicine. Curr Opin Crit Care. (2019) 25:12-20. doi: 10.1097/MCC.0000000000000571

79. Wilson JG, Calfee CS. ARDS subphenotypes: understanding a heterogeneous syndrome. Crit Care. (2020) 24:102. doi: 10.1186/s13054-020-2778-x

80. Rogers AJ, Guan J, Trtchounian A, Hunninghake GM, Kaimal R, Desai $M$, et al. Association of elevated plasma interleukin-18 level with increased mortality in a clinical trial of statin treatment for acute respiratory distress syndrome. Crit Care Med. (2019) 47:1089-96. doi: 10.1097/CCM.0000000000003816

81. Famous KR, Delucchi K, Ware LB, Kangelaris KN, Liu KD, Thompson BT, et al. Acute respiratory distress syndrome subphenotypes respond differently to randomized fluid management strategy. Am J Respir Crit Care Med. (2017) 195:331-8. doi: 10.1164/rccm.201603-0645OC

82. Delucchi K, Famous KR, Ware LB, Parsons PE, Thompson BT, Calfee CS, et al. Stability of ARDS subphenotypes over time in two randomised controlled trials. Thorax. (2018) 73:439-45. doi: 10.1136/thoraxjnl-2017-211090

83. Gu J, Korteweg C. Pathology and pathogenesis of severe acute respiratory syndrome. Am J Pathol. (2007) 170:1136-47. doi: 10.2353/ajpath.2007.061088

84. Garcia LF. Immune response, inflammation, and the clinical spectrum of COVID-19. Front Immunol. (2020) 11:1441. doi: 10.3389/fimmu.2020.01441

85. Kerr N, De Rivero Vaccari JP, Dietrich WD, Keane RW. Neural-respiratory inflammasome axis in traumatic brain injury. Exp Neurol. (2020) 323:113080. doi: 10.1016/j.expneurol.2019.113080

86. Andersson U, Wang H, Palmblad K, Aveberger AC, Bloom O, ErlandssonHarris $\mathrm{H}$, et al. High mobility group 1 protein. (HMG-1) stimulates proinflammatory cytokine synthesis in human monocytes. J Exp Med. (2000) 192:565-70. doi: 10.1084/jem.192.4.565

87. Andersson U, Ottestad W, Tracey KJ. Extracellular HMGB1: a therapeutic target in severe pulmonary inflammation including COVID-19? Mol Med. (2020) 26:42. doi: 10.1186/s10020-020-00172-4

88. Wu CP, Adhi F, Highland K. Recognition and management of respiratory coinfection and secondary bacterial pneumonia in patients with COVID19. Cleve Clin J Med. (2020). doi: 10.3949/ccjm.87a.ccc015. [Epub ahead of print].

89. Witzenrath M, Pache F, Lorenz D, Koppe U, Gutbier B, Tabeling C, et al. The NLRP3 inflammasome is differentially activated by pneumolysin variants and contributes to host defense in pneumococcal pneumonia. J Immunol. (2011) 187:434-40. doi: 10.4049/jimmunol.1003143

90. Kebaier C, Chamberland RR, Allen IC, Gao X, Broglie PM, Hall JD, et al. Staphylococcus aureus alpha-hemolysin mediates virulence in a murine model of severe pneumonia through activation of the NLRP3 inflammasome. J Infect Dis. (2012) 205:807-17. doi: 10.1093/infdis/jir846

91. Cohen TS, Prince AS. Activation of inflammasome signaling mediates pathology of acute P. aeruginosa pneumonia. J Clin Invest. (2013) 123:16307. doi: 10.1172/JCI66142

92. Zhang H, Luo J, Alcorn JF, Chen K, Fan S, Pilewski J, et al. AIM2 inflammasome is critical for influenza-induced lung injury and mortality. $J$ Immunol. (2017) 198:4383-93. doi: 10.4049/jimmunol.1600714

93. Deliwala SS, Ponnapalli A, Seedahmed E, Berrou M, Bachuwa G, Chandran A. A 29-year-old male with a fatal case of COVID-19 acute respiratory distress syndrome. (CARDS) and Ventilator-Induced Lung Injury. (VILI). Am J Case Rep. (2020) 21:e926136. doi: 10.12659/AJCR. 926136

94. Fowler RA, Lapinsky SE, Hallett D, Detsky AS, Sibbald WJ, Slutsky AS, et al. Critically ill patients with severe acute respiratory syndrome. JAMA. (2003) 290:367-73. doi: 10.1001/jama.290.3.367

95. Wu J, Yan Z, Schwartz DE, Yu J, Malik AB, Hu G. Activation of NLRP3 inflammasome in alveolar macrophages contributes to mechanical stretchinduced lung inflammation and injury. J Immunol. (2013) 190:3590-9. doi: 10.4049/jimmunol.1200860

96. Liu H, Gu C, Liu M, Liu G, Wang Y. NEK7 mediated assembly and activation of NLRP3 inflammasome downstream of potassium efflux in ventilator-induced lung injury. Biochem Pharmacol. (2020) 177:113998. doi: 10.1016/j.bcp.2020.113998

97. Dolinay T, Kim YS, Howrylak J, Hunninghake GM, An CH, Fredenburgh $\mathrm{L}$, et al. Inflammasome-regulated cytokines are critical mediators of acute lung injury. Am J Respir Crit Care Med. (2012) 185:1225-34. doi: 10.1164/rccm.201201-0003OC

98. Povoa HCC, Chianca GC, Iorio N. COVID-19: an alert to ventilatorassociated bacterial pneumonia. Infect Dis Ther. (2020) 9:417-20. doi: 10.1007/s40121-020-00306-5

99. Yang X, Yu Y, Xu J, Shu H, Xia J, Liu H, et al. Clinical course and outcomes of critically ill patients with SARS-CoV-2 pneumonia in Wuhan, China: 
a single-centered, retrospective, observational study. Lancet Respir Med. (2020) 8:475-81. doi: 10.1016/S2213-2600(20)30079-5

100. Chastre J, Fagon JY. Ventilator-associated pneumonia. Am J Respir Crit Care Med. (2002) 165:867-903. doi: 10.1164/ajrccm.165.7.2105078

101. Kollef MH. Ventilator-associated pneumonia. a multivariate analysis. JAMA. (1993) 270:1965-70. doi: 10.1001/jama.1993.03510160083034

102. Huang Y, Jiao Y, Zhang J, Xu J, Cheng Q, Li Y, et al. Microbial etiology and prognostic factors of ventilator-associated pneumonia: a multicenter retrospective study in shanghai. Clin Infect Dis. (2018) 67:S146-52. doi: $10.1093 / \mathrm{cid} /$ ciy686

103. Conway Morris A, Kefala K, Wilkinson TS, Moncayo-Nieto OL, Dhaliwal K, Farrell L, et al. Diagnostic importance of pulmonary interleukin-1beta and interleukin-8 in ventilator-associated pneumonia. Thorax. (2010) 65:201-7. doi: 10.1136/thx.2009.122291

104. Mehta P, Mcauley DF, Brown M, Sanchez E, Tattersall RS, Manson JJ, et al. COVID-19: consider cytokine storm syndromes and immunosuppression. Lancet. (2020) 395:1033-4. doi: 10.1016/S0140-6736(20)30628-0

105. Huang C, Wang Y, Li X, Ren L, Zhao J, Hu Y, et al. Clinical features of patients infected with 2019 novel coronavirus in Wuhan, China. Lancet. (2020) 395:497-506. doi: 10.1016/S0140-6736(20)30183-5

106. Sinha P, Matthay MA, Calfee CS. Is a "Cytokine Storm" relevant to COVID-19? JAMA Intern Med. (2020) 180:1152-54. doi: 10.1001/jamainternmed.2020.3313

107. Shimabukuro-Vornhagen A, Godel P, Subklewe M, Stemmler HJ, Schlosser HA, Schlaak M, et al. Cytokine release syndrome. J Immunother Cancer. (2018) 6:56. doi: 10.1186/s40425-018-0343-9

108. Escher R, Breakey N, Lammle B. ADAMTS13 activity, von Willebrand factor, factor VIII and D-dimers in COVID-19 inpatients. Thromb Res. (2020) 192:174-5. doi: 10.1016/j.thromres.2020.05.032

109. Cahill CM, Rogers JT. Interleukin. (IL) 1beta induction of IL- 6 is mediated by a novel phosphatidylinositol 3-kinase-dependent AKT/IkappaB kinase alpha pathway targeting activator protein-1. J Biol Chem. (2008) 283:25900-12. doi: 10.1074/jbc.M707692200

110. Teachey DT, Lacey SF, Shaw PA, Melenhorst JJ, Maude SL, Frey N, et al. Identification of predictive biomarkers for cytokine release syndrome after chimeric antigen receptor T-cell therapy for acute lymphoblastic leukemia. Cancer Discov. (2016) 6:664-79. doi: 10.1158/2159-8290.CD-16-0040

111. Conti P, Ronconi G, Caraffa A, Gallenga CE, Ross R, Frydas I, et al. Induction of pro-inflammatory cytokines. (IL-1 and IL-6) and lung inflammation by Coronavirus-19. (COVI-19 or SARS-CoV-2): anti-inflammatory strategies. J Biol Regul Homeost Agents. (2020) 34:327-31. doi: 10.23812/CONTI-E

112. Day JW, Fox TA, Halsey R, Carpenter B, Kottaridis PD. IL-1 blockade with anakinra in acute leukaemia patients with severe COVID-19 pneumonia appears safe and may result in clinical improvement. Br J Haematol. (2020) 190:e80-e83. doi: 10.1111/bjh.16873

113. Gruber C. Impaired interferon signature in severe COVID-19. Nat Rev Immunol. (2020) 20:353. doi: 10.1038/s41577-020-0335-0

114. Mayer-Barber KD, Andrade BB, Oland SD, Amaral EP, Barber DL, Gonzales J, et al. Host-directed therapy of tuberculosis based on interleukin-1 and type I interferon crosstalk. Nature. (2014) 511:99-103. doi: 10.1038/nature13489

115. Teijaro JR. Type I interferons in viral control and immune regulation. Curr Opin Virol. (2016) 16:31-40. doi: 10.1016/j.coviro.2016.01.001

116. Lin L, Xu L, Lv W, Han L, Xiang Y, Fu L, et al. An NLRP3 inflammasome-triggered cytokine storm contributes to Streptococcal toxic shock-like syndrome. (STSLS). PLoS Pathog. (2019) 15:e1007795. doi: 10.1371/journal.ppat.1007795

117. Xiao H, Li H, Wang JJ, Zhang JS, Shen J, An XB, et al. IL-18 cleavage triggers cardiac inflammation and fibrosis upon beta-adrenergic insult. Eur Heart J. (2018) 39:60-9. doi: 10.1093/eurheartj/ehx261

118. Yao C, Veleva T, Scott L Jr, Cao S, Li L, Chen G, et al. Enhanced cardiomyocyte NLRP3 inflammasome signaling promotes atrial fibrillation. Circulation. (2018) 138:2227-42. doi: 10.1161/CIRCULATIONAHA.118.035202

119. Dalekos GN, Elisaf M, Bairaktari E, Tsolas O, Siamopoulos KC. Increased serum levels of interleukin-1beta in the systemic circulation of patients with essential hypertension: additional risk factor for atherogenesis in hypertensive patients? J Lab Clin Med. (1997) 129:300-8. doi: 10.1016/S0022-2143(97)90178-5
120. Krishnan SM, Dowling JK, Ling YH, Diep H, Chan CT, Ferens D, et al. Inflammasome activity is essential for one kidney/deoxycorticosterone acetate/salt-induced hypertension in mice. Br J Pharmacol. (2016) 173:75265. doi: 10.1111/bph.13230

121. Krishnan SM, Ling YH, Huuskes BM, Ferens DM, Saini N, Chan CT, et al. Pharmacological inhibition of the NLRP3 inflammasome reduces blood pressure, renal damage, and dysfunction in salt-sensitive hypertension. Cardiovasc Res. (2019) 115:776-87. doi: 10.1093/cvr/cvy252

122. Budden KF, Gellatly SL, Wood DL, Cooper MA, Morrison M, Hugenholtz P, et al. Emerging pathogenic links between microbiota and the gut-lung axis. Nat Rev Microbiol. (2017) 15:55-63. doi: 10.1038/nrmicro.2016.142

123. Xiao X, Qi J, Lei X, Wang J. Interactions between enteroviruses and the inflammasome: new insights into viral pathogenesis. Front Microbiol. (2019) 10:321. doi: 10.3389/fmicb.2019.00321

124. Mridha AR, Wree A, Robertson AAB, Yeh MM, Johnson CD, van Rooyen $\mathrm{DM}$, et al. NLRP3 inflammasome blockade reduces liver inflammation and fibrosis in experimental NASH in mice. J Hepatol. (2017) 66:1037-46. doi: 10.1016/j.jhep.2017.01.022

125. Gao L, Lu GT, Lu YY, Xiao WM, Mao WJ, Tong ZH, et al. Diabetes aggravates acute pancreatitis possibly via activation of NLRP3 inflammasome in $\mathrm{db} / \mathrm{db}$ mice. Am J Transl Res. (2018) 10:2015-25.

126. Kerr NA, De Rivero Vaccari JP, Abbassi S, Kaur H, Zambrano R, Wu S, et al. Traumatic brain injury-induced acute lung injury: evidence for activation and inhibition of a neural-respiratory-inflammasome axis. J Neurotrauma. (2018) 35:2067-76. doi: 10.1089/neu.2017.5430

127. Mcgilligan VE, Gregory-Ksander MS, Li D, Moore JE, Hodges RR, Gilmore MS, et al. Staphylococcus aureus activates the NLRP3 inflammasome in human and rat conjunctival goblet cells. PLoS ONE. (2013) 8:e74010. doi: 10.1371/journal.pone.0074010

128. Karthikeyan RS, Priya JL, Leal SMJr, Toska J, Rietsch A, Prajna V, et al. Host response and bacterial virulence factor expression in Pseudomonas aeruginosa and Streptococcus pneumoniae corneal ulcers. PLoS ONE. (2013) 8:e64867. doi: 10.1371/journal.pone.0064867

129. Liu T, Tang L, Tang H, Pu J, Gong S, Fang D, et al. Zika virus infection induces acute kidney injury through activating NLRP3 inflammasome Via suppressing Bcl-2. Front Immunol. (2019) 10:1925. doi: 10.3389/fimmu.2019.01925

130. Boukhris M, Hillani A, Moroni F, Annabi MS, Addad F, Ribeiro MH, et al. Cardiovascular implications of the COVID-19 pandemic: a global perspective. Can J Cardiol. (2020) 36:1068-80. doi: 10.1016/j.cjca.2020.05.018

131. Pan L, Mu M, Yang P, Sun Y, Wang R, Yan J, et al. Clinical characteristics of COVID-19 patients with digestive symptoms in hubei, china: a descriptive, cross-sectional, multicenter study. Am J Gastroenterol. (2020) 115:766-73. doi: 10.14309/ajg.0000000000000620

132. Prasad H, Shenoy AR, Visweswariah SS. Cyclic nucleotides, gut physiology and inflammation. FEBS J. (2020) 287:1970-81. doi: 10.1111/febs.15198

133. Bauer C, Duewell P, Mayer C, Lehr HA, Fitzgerald KA, Dauer M, et al. Colitis induced in mice with dextran sulfate sodium. (DSS) is mediated by the NLRP3 inflammasome. Gut. (2010) 59:1192-9. doi: 10.1136/gut.2009.197822

134. Pawlotsky JM. COVID-19 and the liver-related deaths to come. Nat Rev Gastroenterol Hepatol. (2020) 17:523-5. doi: 10.1038/s41575-020-0328-2

135. Yang JK, Lin SS, Ji XJ, Guo LM. Binding of SARS coronavirus to its receptor damages islets and causes acute diabetes. Acta Diabetol. (2010) 47:193-9. doi: 10.1007/s00592-009-0109-4

136. Huang I, Lim MA, Pranata R. Diabetes mellitus is associated with increased mortality and severity of disease in COVID-19 pneumonia - a systematic review, meta-analysis, and meta-regression. Diabetes Metab Syndr. (2020) 14:395-403. doi: 10.1016/j.dsx.2020.04.018

137. Lee HM, Kim JJ, Kim HJ, Shong M, Ku BJ, Jo EK. Upregulated NLRP3 inflammasome activation in patients with type 2 diabetes. Diabetes. (2013) 62:194-204. doi: 10.2337/db12-0420

138. Abalo-Lojo JM, Pouso-Diz JM, Gonzalez F. Taste and smell dysfunction in COVID-19 patients. Ann Otol Rhinol Laryngol. (2020) 129:3489420932617. doi: 10.1177/0003489420932617

139. Asadi-Pooya AA, Simani L. Central nervous system manifestations of COVID-19: a systematic review. J Neurol Sci. (2020) 413:116832. doi: $10.1016 /$ j.jns.2020.116832 
140. Xu H, Zhong L, Deng J, Peng J, Dan H, Zeng X, et al. High expression of ACE2 receptor of 2019-nCoV on the epithelial cells of oral mucosa. Int J Oral Sci. (2020) 12:8. doi: 10.1038/s41368-020-0074-x

141. Beltran-Corbellini A, Chico-Garcia JL, Martinez-Poles J, RodriguezJorge F, Natera-Villalba E, Gomez-Corral J, et al. Acute-onset smell and taste disorders in the context of COVID-19: a pilot multicentre polymerase chain reaction based case-control study. Eur J Neurol. (2020). doi: 10.1111/ene.14273. [Epub ahead of print].

142. Hung EC, Chim SS, Chan PK, Tong YK, Ng EK, Chiu RW, et al. Detection of SARS coronavirus RNA in the cerebrospinal fluid of a patient with severe acute respiratory syndrome. Clin Chem. (2003) 49:2108-9. doi: 10.1373/clinchem.2003. 025437

143. Zhang BZ, Chu H, Han S, Shuai H, Deng J, Hu YF, et al. SARS-CoV-2 infects human neural progenitor cells and brain organoids. Cell Res. (2020) 30:928-31. doi: 10.1038/s41422-0200390-x

144. Nolte-'T Hoen E, Cremer T, Gallo RC, Margolis LB. Extracellular vesicles and viruses: are they close relatives? Proc Natl Acad Sci USA. (2016) 113:9155-61. doi: 10.1073/pnas.1605146113

145. Loffredo L, Pacella F, Pacella E, Tiscione G, Oliva A, Violi F. Conjunctivitis and COVID-19: a meta-analysis. J Med Virol. (2020). doi: 10.1002/jmv.25938. [Epub ahead of print].

146. Loon SC, Teoh SC, Oon LL, Se-Thoe SY, Ling AE, Leo YS, et al. The severe acute respiratory syndrome coronavirus in tears. Br J Ophthalmol. (2004) 88:861-3. doi: 10.1136/bjo.2003.035931

147. Kipar A, May H, Menger S, Weber M, Leukert W, Reinacher M. Morphologic features and development of granulomatous vasculitis in feline infectious peritonitis. Vet Pathol. (2005) 42:321-30. doi: 10.1354/vp.42-3-321

148. Doherty MJ. Ocular manifestations of feline infectious peritonitis. J Am Vet Med Assoc. (1971) 159:417-24.

149. Seah I, Agrawal R. Can the coronavirus disease 2019. (COVID-19) affect the eyes? a review of coronaviruses and ocular implications in humans and animals. Ocul Immunol Inflamm. (2020) 28:391-5. doi: 10.1080/09273948.2020.1738501

150. de Rivero Vaccari JP, Bastien D, Yurcisin G, Pineau I, Dietrich WD, De Koninck Y, et al. P2X4 receptors influence inflammasome activation after spinal cord injury. J Neurosci. (2012) 32:3058-66. doi: 10.1523/JNEUROSCI.4930-11.2012

151. Gabarre P, Dumas G, Dupont T, Darmon M, Azoulay E, Zafrani L. Acute kidney injury in critically ill patients with COVID-19. Intensive Care Med. (2020) 46:1339-48. doi: 10.1007/s00134-020-06153-9

152. Cao Y, Fei D, Chen M, Sun M, Xu J, Kang K, et al. Role of the nucleotide-binding domain-like receptor protein 3 inflammasome in acute kidney injury. FEBS J. (2015) 282:3799-807. doi: 10.1111/febs. 13379

153. Abernethy K, Sivakumar P, Patrick T, Robbie H, Periselneris J. Coexistent COVID-19 pneumonia and pulmonary embolism: challenges in identifying dual pathology. Thorax. (2020) 75:812-4. doi: 10.1136/thoraxjnl-2020-215011

154. Demelo-Rodriguez P, Cervilla-Munoz E, Ordieres-Ortega L, ParraVirto A, Toledano-Macias M, Toledo-Samaniego $\mathrm{N}$, et al. Incidence of asymptomatic deep vein thrombosis in patients with COVID-19 pneumonia and elevated D-dimer levels. Thromb Res. (2020) 192:23-6. doi: 10.1016/j.thromres.2020.05.018

155. Qiao J, Wu X, Luo Q, Wei G, Xu M, Wu Y, et al. NLRP3 regulates platelet integrin alphaIIbbeta3 outside-in signaling, hemostasis and arterial thrombosis. Haematologica. (2018) 103:1568-76. doi: 10.3324/haematol.2018.191700

156. Wu C, Lu W, Zhang Y, Zhang G, Shi X, Hisada Y, et al. Inflammasome activation triggers blood clotting and host death through pyroptosis. Immunity. (2019) 50:1401-11.e4. doi: 10.1016/j.immuni.2019. 04.003
157. Battaglini D, Robba C, Ball L, Cruz FF, Silva PL, Pelosi P, et al. Emerging therapies for COVID-19 pneumonia. Expert Opin Investig Drugs. (2020) 29:633-37. doi: 10.1080/13543784.2020.1771694

158. Coll RC, Hill JR, Day CJ, Zamoshnikova A, Boucher D, Massey NL, et al. MCC950 directly targets the NLRP3 ATP-hydrolysis motif for inflammasome inhibition. Nat Chem Biol. (2019) 15:556-9. doi: 10.1038/s41589-019-0277-7

159. Cain DW, Cidlowski JA. After 62 years of regulating immunity, dexamethasone meets COVID-19. Nat Rev Immunol. (2020) 20:587-88. doi: 10.1038/s41577-020-00421-x

160. Guan M, Ma H, Fan X, Chen X, Miao M, Wu H. Dexamethasone alleviate allergic airway inflammation in mice by inhibiting the activation of NLRP3 inflammasome. Int Immunopharmacol. (2020) 78:106017. doi: 10.1016/j.intimp.2019.106017

161. Kerr NA, De Rivero Vaccari JP, Weaver C, Dietrich WD, Ahmed T, Keane RW. Enoxaparin attenuates acute lung injury and inflammasome activation after traumatic brain injury. J Neurotrauma. (2020). doi: 10.1089/neu.2020.7257. [Epub ahead of print].

162. Wang T, Chen R, Liu C, Liang W, Guan W, Tang R, et al. Attention should be paid to venous thromboembolism prophylaxis in the management of COVID-19. Lancet Haematol. (2020) 7:e362-3. doi: 10.1016/S2352-3026(20)30109-5

163. Kopitar-Jerala $\mathrm{N}$. The role of interferons in inflammation and inflammasome activation. Front Immunol. (2017) 8:873. doi: 10.3389/fimmu.2017.00873

164. Jalkanen J, Hollmen M, Jalkanen S. Interferon beta-1a for COVID-19: critical importance of the administration route. Crit Care. (2020) 24:335. doi: 10.1186/s13054-020-03048-5

165. Jiang W, Zhu FG, Bhagat L, Yu D, Tang JX, Kandimalla ER, et al. A Tolllike receptor 7, 8, and 9 antagonist inhibits Th1 and Th17 responses and inflammasome activation in a model of IL-23-induced psoriasis. J Invest Dermatol. (2013) 133:1777-84. doi: 10.1038/jid.2013.57

166. van Der Made CI, Simons A, Schuurs-Hoeijmakers J, van Den Heuvel G, Mantere T, Kersten S, et al. Presence of genetic variants among young men with severe COVID-19. JAMA. (2020) 324:1-11. doi: 10.1001/jama.2020. 13719

167. Patra R, Chandra Das N, Mukherjee S. Targeting human TLRs to combat COVID-19: a solution? J Med Virol. (2020). doi: 10.1002/jmv. 26387. [Epub ahead of print].

168. Langer-Gould A, Smith JB, Gonzales EG, Castillo RD, Garza Figueroa J, Ramanathan A, et al. Early identification of COVID-19 cytokine storm and treatment with anakinra or tocilizumab. Int J Infect Dis. (2020) 99:291-7. doi: 10.1016/j.ijid.2020.07.081

169. Martinez-Aguilar L, Perez-Ramirez C, Maldonado-Montoro MDM, Carrasco-Campos MI, Membrive-Jimenez C, Martinez-Martinez F, et al. Effect of genetic polymorphisms on therapeutic response in multiple sclerosis relapsing-remitting patients treated with interferon-beta. Mutat Res. (2020) 785:108322. doi: 10.1016/j.mrrev.2020.108322

Conflict of Interest: JCdRV is employed by DRV Ventures, LLC. JPdRV, RWK, and WDD are co-founders and managing members of InflamaCORE, LLC and have licensed patents on inflammasome proteins as biomarkers of injury and disease as well as on targeting inflammasome proteins for therapeutic purposes. JPdRV, RWK, and WDD are Scientific Advisory Board Members of ZyVersa Therapeutics. JCdRV has licensed a patent on inflammasome proteins as biomarkers.

Copyright $\odot 2020$ de Rivero Vaccari, Dietrich, Keane and de Rivero Vaccari. This is an open-access article distributed under the terms of the Creative Commons Attribution License (CC BY). The use, distribution or reproduction in other forums is permitted, provided the original author(s) and the copyright owner(s) are credited and that the original publication in this journal is cited, in accordance with accepted academic practice. No use, distribution or reproduction is permitted which does not comply with these terms. 